\title{
The Relationship Between Strategic Information Systems Planning (SISP) and Facilitators to Achieve Successful Business Outcomes in South Korean Organizations
}

\author{
Jungho Yang ${ }^{1}$, Nelson K. Y. Leung ${ }^{2}$ and Bill Young ${ }^{1}$ \\ ${ }^{1}$ Swinburne University of Technology, Victoria, Australia \\ ${ }^{2}$ Edith Cowan University, Western Australia, Australia \\ junghovang@swin.edu.au \\ k.leung@ecu.edu.au \\ wayoung@swin.edu.au \\ DOI: 10.34190/EJISE.20.23.1.009
}

Abstract: Strategic Information Systems Planning (SISP) is an important process in the implementation and use of IT systems in today's dynamic and increasingly digitalized organizations. However, SISP is not a straightforward task, it is a process that covers simultaneous multiple planning issues often in changing environmental and organizational climates. Although SISP has been widely studied, and evaluating the SISP process has matured, theory on SISP facilitators that enable successful outcomes remain sparse. The main objective of this paper is to explore such facilitators and to investigate their relationship and contribution in achieving SISP success. By postal surveying a random sample of managers with SISP experience in South Korean organizations, we modeled the relationship between facilitators of SISP and their outcomes. The study used Structural Equation Modelling to analyze and validate its findings. This study suggests that facilitators positively affect successful SISP through business and IT alignment. It also demonstrates that effective SISP has a positive effect on organizational outcomes by ensuring organizational capabilities and IT infrastructure flexibility. The findings of this study expounding the role of facilitators adds to the theory of SISP and provides a guide to planners and managers responsible for information systems.

Keywords: Strategic information systems planning, SISP, business and IT alignment, organizational capabilities, IT infrastructure flexibility

\section{Introduction}

In the current rapidly changing and highly dynamic business environments, information systems (IS) and information technology (IT) have become essential entities for organizational growth and survival (Kappelman et al., 2017; Kitsios and Kamariotou, 2019b; Lee and Chen, 2019; Luftman et al., 2013; McNurlin et al., 2009; Silvius and Stoop, 2013). Particularly organizations trying to achieve competitive advantage (Hung et al., 2016; Peppard and Ward, 2016). The current business trends in organizations have also emerged around some dominant drivers based on IT innovations, such as globalization (Gable, 2010; Grant et al., 2010), virtualization (Rainey, 2010) and digital business such as e-commerce, mobile commerce and social media (Beynon-Davies, 2020; Urbach et al., 2019). Since IS/IT is a critical requirement for all aspects of business operations, strategic information systems planning (SISP) is a vital process for organizational success (Lientz, 2010; Otim et al., 2009; Wallace, 2013). It is a fundamental decision-making process that enables IS/IT business goals to be achieved (Hung et al., 2016; Lee et al., 2015; Peppard et al., 2014).

In order to be flexible and systematic with the implementation and use of IS/IT, organizations need to take multiple planning perspectives by considering their environmental, managerial and organizational factors during SISP (Ali et al., 2018; Bechor et al., 2010; Chi et al., 2005; Kamariotou and Kitsios, 2019a, b; King, 2009; Urbach et al., 2019). Therefore, organizations need to consider possible 'facilitators' as factors leading to successful SISP. Facilitators of SISP support organizations to achieve their business goals and strategies, to enhance organizational performance, and to secure competitive advantage, which is the ideal outcome obtained from the SISP success (Peppard and Ward, 2016; Yeh et al., 2011; Zwass, 2009). However, to date, prior literature has discussed one or a few facilitator(s) individually and has not addressed holistically what the advisable set of facilitators for SISP success is. Despite the importance of SISP for organizational success in the past decade, SISP theories and methods still lack the capabilities (Arvidsson et al., 2014; Choi and Bae, 2007; Doherty and Terry, 2009) and flexibility (Palanisamy, 2005; Tallon, 2009; Yeh et al., 2011) to support SISP systematically in the

(CACPIL

Reference this paper: Yang, J., Leung, N. K. Y., and Young, B., 2020. The Relationship Between Strategic Information Systems Planning (SISP) and Facilitators to Achieve Successful Business Outcomes in South Korean Organizations. The Electronic Journal of Information Systems Evaluation, 23(1), pp. 126-149, available online at www.ejise.com 
current digital environment (Beynon-Davies, 2020; Grant et al., 2010; Kannabrian and Sundar, 2011). Prior studies have also insufficiently examined the relationship between facilitators for SISP success and how their influence impacts organizational outcomes.

Domestically and internationally, South Korea has long been regarded as one of the leaders in information and communication technologies (ICT) (Hong and Hwang, 2011) and e-business and m-business (National Information Society Agency (NIA), 2017). However, about 50\% of South Korean large organizations have formally conducted SISP activities with the rest taking an informal approach to SISP (NIA, 2017). According to the recent report in NIA (2019), most large companies currently have an IS/IT department and have invested significantly in IS/IT to effectively adapt to the digital management environment. However, top management's interest and understanding of the strategic use of IT appears still low. IT strategic planning personnel within IS/IT departments are far fewer than IT analysts and developers. Further, earlier studies on SISP have mostly focused on North America (USA and Canada), Western and Northern Europe (UK, Finland, and Sweden), and the Asia Pacific (Australia, China, Singapore, and Taiwan). Despite the diffusion and penetration of IS/IT in South Korean organizations being high to date, there have been few studies pertaining to SISP and facilitators essential for SISP success and its outcomes.

This paper examines the importance of facilitators in successful SISP implementation and the relationship between such facilitators and the organizational outcomes in a South Korean context. It answers two main research questions:

RQ1: What are the facilitators essential for successful SISP?

RQ2: What is the relationship between SISP facilitators and the outcome of SISP success?

The remainder of the paper is organized as follows. In the next section, we review background information on SISP to discuss SISP facilitators, SISP success and the outcome of SISP success. We then describe the study's research design and method as well as the information of selected organizations. Following on the findings and quantitative analysis of the survey are explained. We discuss these empirical findings and interpret the importance of the relationship between the facilitators of SISP and the outcome of SISP success. The last section offers the theoretical and practical implications of the findings with concluding remarks.

\section{Literature Review}

\subsection{Strategic Information Systems Planning (SISP)}

The definitions of SISP have evolved incorporating the developments in IT systems, and the dynamic and rapid changes taking place in the globalized business environment (Grover and Segars, 2005; Mirchandani and Lederer, 2012; Peppard and Ward, 2016; Spil et al., 2010). SISP is defined as "the process of identifying a portfolio of computer-based applications that will assist an organization in executing its business plans and consequently realizing its business goals", and "searching for applications with a high impact and ability to create an advantage over competitors" (Lederer and Sethi, 1988, p. 446). Both Earl (1993) and Doherty et al. (1999) confirmed SISP as an on-going activity for developing priorities for IS development with two main aspects, such as 'aligning IS investment with business goals' and 'exploiting IT for competitive advantage'. Bechor et al. (2010) defined SISP as the process of strategic thinking that identifies the most desirable IS/IT on which the firm can implement and enforce its long-term IT activities and policies. Ravichandran (2018) also claimed that strategic IS planning is regarded as a key process that enables organizations to identify business priorities and make sure that IS goals and strategies are aligned. Based on the definition shown, we define SISP as an on-going planning process for identifying organizational needs and potential opportunities. It prioritizes key business and IT activities, supports organizations in implementing and deploying IT systems on achieving corporate strategic objectives. Further, SISP is currently considered as one of the critical components for IT governance (Gregory et al., 2018; Maharaj and Brown, 2015; Wilkin and Chenhall, 2010) and enterprise architecture (Őri, 2018).

As the main objective, SISP supports an alignment of business and IT strategies (Karanja and Patel, 2012; Reich and Benbasat, 2000; Tallon, 2007) for achieving a competitive advantage (Earl, 1993; Hung et al., 2016; Peppard et al., 2014; Teo, 2009). SISP also enables organizations to attain various objectives, such as improving systems' architecture, infrastructure capability and reliability from IS/IT investments (Cassidy, 2006; Gable, 2010; Merali et al., 2012), managing information resources more effectively (Arvidsson et al., 2014; Philip, 2009), improving collaboration between organizational stakeholders (Kamariotou and Kitsios, 2019a; McNurlin et al., 2009), and 
securing user satisfaction (Lientz, 2010; Peppard and Ward, 2016). Thus, SISP helps organizations to provide a road map that optimize the benefits of their IT investment (Bechor et al., 2010; Hung et al., 2016; Teubner, 2013). Based on the SISP, organizations adjust and combine their business and IT purposes to enhance their performance (Grover and Segars, 2005; Peppard and Ward, 2016; Wallace, 2013) and meet their current and future business challenges (Amrollahi et al., 2013; Bhatt, 2009; Peppard at al., 2014; Yeh et al., 2011).

SISP is the process that consists of a broad set of factors and complex tasks including; stakeholder engagement (top management, IT managers, end-users, etc), understanding and interacting with the internal and external business environments, and ultimately aligning all decisions to the organization's vision and mission. (Hung et al., 2016; King, 2009; Newkirk et al., 2008; Peppard et al., 2014). The insufficient undertaking of SISP results in the repetitive implementation of IT systems that tend to be inflexible and incompatible, sometimes not resulting in the anticipated benefits and opportunities from the IT investment (Ali et al., 2018; Kamariotou and Kitsios, 2019b; Lientz, 2010; Őri, 2018; Yeh et al., 2011). However, undertaking SISP is not an easy task (Cassidy 2006; McNurlin et al. 2009), because of organizational differences in cultures, business directions, objectives, and strategies (Bechor et al., 2010; Wallace, 2013). Further, although there have been various approaches or methodologies of SISP proposed, there is no one universal way of undertaking SISP, and there is no consensus on the dimensions of a SISP process (Amrollahi et al., 2013; Palanisamy, 2005; Silvius and Stoop, 2013; Peppard and Ward, 2016). For such reasons, SISP has become a critical topic to both academics and practitioners, and one of the top 10 most important IT management issues in both developed and developing countries since 1980 (Amrollahi et al., 2013; Hung et al., 2016; Kamariotou and Kitsios, 2019a; Kappelman et al., 2014, 2017; Maharaj and Brown, 2015; Luftman et al., 2013).

\subsection{SISP Facilitators}

To facilitate the overall level of SISP success, organizations need to consider and understand various factors that are essential for SISP. SISP success is dependent upon a function of many variables (Gottschalk, 1999; Peppard and Ward, 2016; Wallace, 2013). A summary of the five factors that facilitate SISP success is shown in Table 1.

Table 1: Summary of the five factors facilitating SISP success

\begin{tabular}{|c|c|c|c|}
\hline Domain & Construct & Description & References \\
\hline \multirow[t]{5}{*}{$\begin{array}{l}\text { SISP success } \\
\text { factors as } \\
\text { 'antecedents' }\end{array}$} & $\begin{array}{l}\text { Top management } \\
\text { participation and } \\
\text { support (TMPS) }\end{array}$ & $\begin{array}{l}\text { The overall degree to which top } \\
\text { management of the organization is } \\
\text { interested in, participates in, and supports } \\
\text { SISP, and IS-related efforts. }\end{array}$ & $\begin{array}{l}\text { Ali et al., 2018; Basu et al., } \\
\text { 2002; Elbanna, 2013; García- } \\
\text { Sánchez et al., 2019; Kearns, } \\
\text { 2006; Kitsios and Kamariotou, } \\
\text { 2019b; Philip, 2007, 2009; } \\
\text { Ragu-Nathan et al., } 2004\end{array}$ \\
\hline & $\begin{array}{l}\text { Active } \\
\text { communication and } \\
\text { knowledge sharing } \\
\text { between business } \\
\text { and IT sectors } \\
\text { (ACKS) }\end{array}$ & $\begin{array}{l}\text { The overall effort of business and IT sectors } \\
\text { in an organisation to communicate and } \\
\text { share their ideas and information with each } \\
\text { other to undertake and realise an effective } \\
\text { SISP process. }\end{array}$ & $\begin{array}{l}\text { Al Nahyan et al., 2019; } \\
\text { Ilmudeen et al., 2019; } \\
\text { McNurlin et al., 2009; Pai, } \\
\text { 2006; Park and Kim, 2018; } \\
\text { Preston and Karahanna, 2009; } \\
\text { Piccoli, 2008; Yeh et al., 2011 }\end{array}$ \\
\hline & $\begin{array}{l}\text { Consideration of } \\
\text { internal and } \\
\text { external } \\
\text { environment (CIEE) }\end{array}$ & $\begin{array}{l}\text { The activity of an organization to examine } \\
\text { and identify important business and IT } \\
\text { factors or issues regarding the SISP } \\
\text { undertaking by considering situations } \\
\text { inside and outside the organization. }\end{array}$ & $\begin{array}{l}\text { Chi et al., 2005; Hung et al., } \\
\text { 2016; Kearns, 2007; King, } \\
\text { 2009; Kitsios and Kamariotou, } \\
\text { 2019a; Newkirk et al., 2008; } \\
\text { Sabherwal et al., 2019; } \\
\text { Wallace, 2013; }\end{array}$ \\
\hline & $\begin{array}{l}\text { Appropriate } \\
\text { resources } \\
\text { allocation for SISP } \\
\text { (ARA) }\end{array}$ & $\begin{array}{l}\text { The activity of an organization to } \\
\text { adequately allocate and invest various } \\
\text { resources necessary for the SISP process, } \\
\text { such as financial, human, and technical } \\
\text { resources to lead its effective undertaking. }\end{array}$ & $\begin{array}{l}\text { Brown, 2004; Jorfi et al., 2017; } \\
\text { Kearns and Lederer, 2000; } \\
\text { Philip, 2007, 2009; Rondeau et } \\
\text { al., 2010; Peppard and Ward, } \\
2016\end{array}$ \\
\hline & $\begin{array}{l}\text { Performing } \\
\text { organisational } \\
\text { learning (POL) }\end{array}$ & $\begin{array}{l}\text { The activity of an organization to learn } \\
\text { overall processes that result in the creation } \\
\text { of new knowledge and structures vital to } \\
\text { SISP. The activity to explain to all users of } \\
\text { the organization the expected changes and } \\
\text { solutions to potential issues followed by } \\
\text { the process. }\end{array}$ & $\begin{array}{l}\text { Argote, 2005; Bhatt and } \\
\text { Grover, 2005; Hovelja et al., } \\
\text { 2010; Otim et al., 2009; Park } \\
\text { and Kim, 2018; Peppard and } \\
\text { Ward, 2004; Reponen, } 1998\end{array}$ \\
\hline
\end{tabular}




\begin{tabular}{|l|l|l|l|}
\hline \multicolumn{1}{|c|}{ Domain } & \multicolumn{1}{c|}{ Construct } & \multicolumn{1}{c|}{ Description } & \multicolumn{1}{c|}{ References } \\
\hline $\begin{array}{l}\text { Successful } \\
\text { Sutcomes of }\end{array}$ & $\begin{array}{l}\text { Business and IT } \\
\text { alignment (BITA) }\end{array}$ & $\begin{array}{l}\text { The extent to which the mission, } \\
\text { objectives, and plans contained in the } \\
\text { business strategy are closely linked, shared, } \\
\text { and supported by the IT mission, } \\
\text { objectives, and plans. }\end{array}$ & $\begin{array}{l}\text { Chan, 2002; Earl, 1993; } \\
\text { Ilmudeen et al., 2019; Kitsios } \\
\text { and Kamariotou, 2019b; } \\
\text { Maharaj and Brown, 2015; } \\
\text { Öri, 2018; Reich and Benbasat, } \\
\text { 1996, 2000; Teo, 2009 }\end{array}$ \\
\hline $\begin{array}{l}\text { The impact of } \\
\text { SISP success }\end{array}$ & $\begin{array}{l}\text { Organisational } \\
\text { capabilities (Orcap) }\end{array}$ & $\begin{array}{l}\text { The ability of the firm to combine and } \\
\text { reconfigure its resources and processes to to } \\
\text { gain the desired goal and sustainable } \\
\text { competitive advantage. }\end{array}$ & $\begin{array}{l}\text { Amit and Schoemaker, 1993; } \\
\text { Duhan, 2007; Grant, 1996; } \\
\text { Peppard and Ward, 2004; Teo, } \\
\text { 2009 }\end{array}$ \\
\cline { 2 - 5 } & $\begin{array}{l}\text { IT infrastructure } \\
\text { flexibility (ITIF) }\end{array}$ & $\begin{array}{l}\text { H/W, S/W, networks, and technical skills to } \\
\text { generate a tighter fit between business and } \\
\text { IT strategies to move quickly and to } \\
\text { broaden strategic experiments }\end{array}$ & $\begin{array}{l}\text { Arvidsson et al., 2014; Bhatt, } \\
\text { 2009; Broadbent et al., 1999; } \\
\text { Byrd and Turner, 2000; } \\
\text { Duncan, 1995; Tallon, 2009; } \\
\text { Ravichandran, 2018 }\end{array}$ \\
\hline
\end{tabular}

\subsubsection{Top management participation and support}

It has been discussed in prior literature (Kamariotou and Kitsios, 2019a; Kearns 2006; Pai, 2006; Papke-Shields et al., 2002; Stemberger et al., 2011) that the more participation and support top management provides positively impacts the fulfillment of SISP and its greater success. This is because such participation and support influences other users within an organization to see greater value in SISP and IT projects (Ali et al., 2018; Ateş et al., 2020; García-Sánchez et al., 2019; Grant et al., 2010). Without such support SISP commonly encounters issues especially in the analysis, design and development stages of the IS/IT systems; there then results in a business / IT gap in the organization (Kitsios and Kamariotou, 2019b; Salmela et al., 2000; Stemberger et al., 2011; Teo and Ang, 2001; Teubner, 2013). Hence, top management needs to be well versed with the organization's purposes and principles for SISP as decision-makers (Ali et al., 2018; Ateş et al., 2020; Gopalakrishna-Remani et al., 2019; Philip, 2007, 2009). Additionally, they need to maintain continuous interaction between organizational members with a positive mind-set to lead successful SISP (Grant et al., 2010; Wallace, 2013).

According to Ali et al. (2018), Kearns (2006), Philip (2009), Stemberger et al. (2011), and Teubner (2013), top management participation and support during SISP has a far-reaching effect on its outcome and level of IS planning sophistication (Ravichandran, 2018). Its impact includes improved understanding of the strategic role that IT members play providing managerial opinion of opportunities that are important for business success (Kearns, 2006; Kearns and Sabherwal, 2007; Peppard and Ward, 2016). It additionally enhances various stakeholder communication and knowledge-sharing (Byrd et al., 2006; Elbanna, 2013; Gopalakrishna-Remani et al., 2019; Teubner, 2013).

The participation and support of top management also contributes to ensuring sufficient resource allocation for SISP (García-Sánchez et al., 2019; Kearns, 2006; Teo and Ang, 2001; Stemberger et al., 2011; Young and Jordan 2008); realizing effective business and IT alignment (Hung et al., 2016; Elbanna, 2013; Kearns, 2006 Kitsios and Kamariotou, 2019b), elevating the effectiveness of IS/IT assimilation (Liang et al., 2007; Ravichandran, 2018; Shao, 2019), and facilitating SISP and IT project performance (Elbanna, 2013; García-Sánchez et al., 2019; Parolia et al., 2007). Thus, the following hypothesis is proposed:

Hypothesis 1: Top management participation and support have a positive effect on achieving SISP success.

\subsubsection{Active communication and knowledge sharing between business and IT sector}

Communication and knowledge-sharing between business and IT members is essential to lead successful SISP because business and IT members or sectors in the organization commonly have different tacit knowledge (Al Nahyan et al., 2019; Lee and Bai, 2003; Park and Kim, 2018; Pai, 2006; Yeh et al., 2011). SISP is recognized as the planning process, which requires discussion, clarification, negotiation, and mutual understanding between the business and IT stakeholders (Maharaj and Brown, 2015; McNurlin et al., 2009; Oyemomi et al., 2019; Teubner, 2013). However, employees who work in the business and IT sector usually find it difficult to communicate and share their information and knowledge due to individualism (Kovacic, 2004), cultural conservatism (Arvidsson et al., 2014) and cultural difference in the two sectors (Shao, 2019; Oyemomi et al., 2019). There tends to be a gap between business requirements and the ability of IT personnel to understand the requirements for business strategy (Al Nahyan et al., 2019; Philip, 2009; Teo and Ang, 2001) and strategic intent (Arvidsson et al., 2014) in 
the organization. Thus, communication and knowledge-sharing between business and IT sectors during SISP are essential to realizing organizational strategic and operational objectives (Peppard et al., 2014; Segars and Grover, 1999; Yeh et al. 2011).

Communication and knowledge-sharing normally encourages organizations to improve collaboration (Byrd et al., 2006; Ilmudeen et al., 2019; Lee and Bai, 2003; Lee and Chen, 2019; Park and Kim, 2018; Teubner, 2013), creation of intra-organizational linkages (Hatzakis et al., 2005; Pai, 2006), and understanding the current business and IT environment between their various members (Maharaj and Brown, 2015; Peppard and Ward, 2016). Further, it helps organizational members achieve mutual trust and credibility of IT (Oyemomi et al., 2019; Philip, 2007, 2009, Wallace, 2013) and diminishes costs and risks (Al Nahyan et al., 2019; Pai, 2006; Segars and Grover, 1999; Yeh et al., 2011). Effective communication and knowledge sharing between business and IT sectors plays an important role in facilitating the quality of SISP and the level of SISP success (Byrd et al., 2006; Lee and Bai, 2003; Pai, 2006; Teubner, 2013; Yeh et al., 2011) based on the achievement of effective business and IT alignment (Carrillo et al., 2019; Shao, 2019; Gutierrez et al., 2009; Ilmudeen et al., 2019; Maharaj and Brown, 2015; Pai, 2006; Reich and Benbasat, 2000). Therefore, the following hypothesis is proposed:

Hypothesis 2: $\quad$ Active communication and knowledge-sharing between business and IT sectors has a positive effect on achieving SISP success.

\subsubsection{Consideration of the internal and external environment}

Business and IT activities of an organization are commonly measured and prioritised by their internal and external environmental changes and opportunities (Ali et al., 2018; Globocnik et al., 2020; Kamariotou and Kitsios, 2019b; Kitsios and Kamariotou, 2019a; Mirchandani and Lederer, 2012; Newkirk et al., 2008; Sabherwal et al., 2019; Spil et al., 2010). The internal environments important to consider during SISP encompass organizational culture and size, and its business objectives, resources, strategies, and structures (Earl, 1993; Hung et al., 2016; McNurlin et al., 2009; Peppard and Ward, 2016; Silvius and Stoop, 2013) as well as IS/IT related budget and skills, IT infrastructure, and maturity (Kannabiran and Sundar, 2011; Lientz, 2010; Wallace, 2013). The external environments essential for SISP include competitors' actions, customer preferences, supplier trends, and economic climate (Chi et al., 2005; Kannabiran and Sundar, 2011; Piccoli, 2008). IT trends and opportunities and the use of IT by competitors and suppliers also impacts (Hung et al., 2016; King, 2009; Newkirk and Lederer 2007; Salmela et al., 2000). Therefore, organizations need to consider and understand complex relationships between internal and external environments for SISP to be successful (Bechor et al., 2010; Chi et al., 2005; Globocnik et al., 2020; Kamariotou and Kitsios, 2019b; Kitsios and Kamariotou, 2019a; Spil et al., 2010; Teubner, 2013). This is because the internal and external business-IT environments influence significantly both the direction and pace of SISP in its strategic use of IT (Chi et al., 2005; Gottschalk, 2007; Newkirk et al., 2008; Peppard and Ward, 2016; Sabherwal et al., 2019; Salmela et al., 2000).

Proper consideration of the internal and external environments during SISP helps organizations recognize the impact of business and IT changes and opportunities. By so doing enables a better more strategic response to business and IT objectives (Chi et al., 2005; Earl, 1993; Newkirk et al., 2008; Teubner, 2013). The importance of considering the environmental factors in SISP is related to improving organizations' impact particularly on the global business markets, dealing effectively with the speed business is changing (Kannabiran and Sundar, 2011; Gottschalk, 2007; Grant et al., 2010; Peppard and Ward, 2016). Prior studies have argued that the more comprehensive SISP is conducted in internal and external environments where uncertainty prevails the likelier it will be successful (King, 2009; Mirchandani and Lederer, 2012; Newkirk and Lederer, 2007; Sabherwal et al., 2019; Silvius and Stoop, 2013; Spil et al., 2010; Teubner, 2013). Furthermore, it enables organisations to improve effective business and IT alignment (Chi et al., 2005; Hung et al., 2016; Globocnik et al., 2020; Kamariotou and Kitsios, 2019b; Kitsios and Kamariotou, 2019a; Newkirk and Lederer, 2006; Newkirk et al., 2008; Tai et al., 2019) and as a result sustain a superior performance (Merali et al., 2012; Newkirk et al., 2008; Peppard and Ward, 2004; Sabherwal et al., 2019; Salmela et al., 2000; Teubner, 2013). Thus, the following hypothesis is proposed:

Hypothesis 3: Consideration of the internal and external environments has a positive effect on achieving SISP success.

\subsubsection{Appropriate resource allocation for SISP}

Resources needed for SISP typically include people (Lientz, 2010; Piccoli, 2008; Tai et al., 2019; Teubner, 2013), financial resources (Cassidy, 2006; Spil et al., 2010; Wallace, 2013), IT-related resources, such as network support, application, hardware/software support, system operations and security services (Jorfi et al., 2017; 
Lientz, 2010; Newkirk and Lederer, 2007) and adequate scheduling time for SISP (Gerow et al., 2016; PapkeShields et al., 2002; Peppard and Ward, 2016). Appropriate allocation of resources during SISP is vital to maintain and support the organization's overall activities and strategies (Arvidsson et al., 2014; McNurlin et al., 2009; Piccoli, 2008). If organizations lack the necessary resources in SISP, it leads to delaying or slowing down the progress of strategy implementation (Lientz, 2010; Peppard and Ward, 2016).

Appropriate resource allocation helps organizations realize successful SISP based on effective business and IT planning (Cassidy, 2006; Samaha and Baki, 2009; Teubner, 2013). It also enables achieving improved alignment of business and IT goals and strategies (Gerow et al., 2016; Jorfi et al., 2017; Newkirk and Lederer, 2007; Shao, 2019; Wallace, 2013), which results in obtaining sustainable organizational performance and competitive advantage (Bechor et al., 2010; Merali et al., 2012; Peppard and Ward, 2016). This creates value for customers to be able to differentiate themselves from competitors (Arvidsson et al., 2014; Grant et al. 2010). Building on the above, the following hypothesis is proposed:

Hypothesis 4: Appropriate resource allocation has a positive effect on achieving SISP success.

\subsubsection{Performing organizational learning}

Organizational learning is defined as a change in the organization's knowledge that occurs as a function of experience (Argote and Miron-Spektor, 2011). Organizational learning is also viewed as a set of processes in which members of an organization improve behavior through better knowledge acquisition and understanding (Carrillo et al., 2019; Govuzela and Mafini, 2019; Park and Kim, 2008). Organizations in the current rapidly changing business environment are concerned with learning complex planning and systems to enhance effective decision-making, and to find ways to understand the behavior of the planning and systems (Grant et al., 2010; Rainey, 2010). Further, SISP and IT-related tasks in an organization are accompanied by a large investment in formal organizational learning (Grover and Segars, 2005; Olfman and Pitsatorn, 2000; Otim et al., 2009). During the SISP, the main objective of organizational learning is to enable the members of an organization to consider existing tasks and execute new tasks effectively, thus, to increase their quality of work (Govuzela and Mafini, 2019; Sharma and Yetton, 2007). It also helps organizational members to recognize changes in the external environment and the expected solutions to potential issues (Otim et al., 2009). Therefore, organizational learning is regarded as a factor for successful SISP (Grover and Segars, 2005; Otim et al., 2009; Teubner, 2013; Wang and Tai, 2003).

Through organizational learning, organizations judge the merits and risks of SISP and proposed IT projects as well as create concrete procedures for measuring the effectiveness of the plan (Argote and Miron-Spektor, 2011; Peppard and Ward, 2016; Sharma and Yetton 2007). It also facilitates the role knowledge and knowledge-based processes by gathering, storing, analyzing, synthesizing and using the organization's information effectively, thus improving better communication and knowledge sharing (Govuzela and Mafini, 2019; Grover and Segars, 2005; Pai, 2006; Palanisamy, 2005). SISP is viewed as a learning process by integrating the organization's capability into its strategy (Otim et al., 2009; Teubner, 2013; Wang and Tai, 2003). Organizational learning experienced in SISP results in improved ability to align business and IT objectives and strategies (Merali et al., 2012; Newkirk and Lederer, 2007), the collaboration between business and IT members (Grover and Segars, 2005; Newkirk and Lederer, 2006; Park and Kim, 2008), and anticipate and adapt to organizational and environmental changes (Otim et al., 2009; Peppard and Ward, 2016). One of the key outcomes in organizational learning is to realize organizational performance based on the progress of IT capabilities and competencies (Govuzela and Mafini, 2019; Grant et al., 2010; Grover and Segars, 2005; Lin and Hsu, 2010; Peppard and Ward, 2004). Furthermore, Park and Kim (2018) have identified that organizational learning as a planning process leads to business change by impacting relationships, strategies, vision as well as by overcoming and solving systemic issues. It also enables organizations to increase their value through innovation (Park and Kim, 2018). Thus, the following hypothesis is proposed:

Hypothesis 5: Performing organizational learning has a positive effect on achieving SISP success.

\subsection{SISP Success}

Prior literature has argued that if organizations focus on considering the effect and importance of factors necessary for undertaking SISP, they are more likely to ensure a greater level of SISP success by attaining improved alignment of business and IT purposes and strategies (Earl, 1993; Grover and Segars, 2005; Hung et al., 2016; Ilmudeen et al., 2019; Karanja and Patel, 2012; Kitsios and Kamariotou, 2019b; Newkirk and Lederer, 
2007; Otim et al., 2009; Papke-Shields et al., 2002; Reich and Benbasat, 2000; Silvius and Stoop, 2013; Teo, 2009). Business and IT alignment is defined as the extent to which the organization's IT goals, mission and plans support the organization's business strategy (Reich and Benbasat, 1996). It also refers to the alignment of IT infrastructure, goals, strategies, and processes with that of the organization (Karpovsky and Galliers, 2015; Tai et al., 2019; Teo, 2009).

As the key objective of SISP, business and IT alignment enable organizations to sustain long-term performance and competitive advantage, such that they realize business success (Earl, 1993; Grover and Segars, 2005; Ilmudeen et al., 2019; Kamariotou and Kitsios, 2019b; Karpovsky and Galliers, 2015; Hirschheim and Sabherwal, 2001; Merali et al., 2012; Őri, 2018). Several prior works of literature have also attested to SISP success being measured by how effective business and IT alignment is achieved (Grover and Segars, 2005; Kamariotou and Kitsios, 2019a,b; Kearns and Sabherwal, 2007; Maharaj and Brown, 2015; Newkirk and Lederer, 2006; Reich and Benbasat, 2000; Segars and Grover, 1998; Silvius and Stoop, 2013; Teo, 2009).

Business and IT alignment enable organizations to achieve success (Arvidsson et al., 2014; Kearns and Sabherwal, 2007; Preston and Karahanna, 2009; Merali et al., 2012) through providing an effective basis for making decisions on organizational resources (Hung et al., 2016; Kannabiran and Sundar, 2011; Peppard and Ward, 2004; Shao, 2019) and strategic opportunities (Duhan, 2007; Peppard et al., 2014; Tai et al., 2019). If business and IT are aligned in their key processes, the organization is more likely to ensure a flexibility to react to new opportunities and increase the business value of its IT investments (Govuzela and Mafini, 2019; Liang et al., 2017; Preston and Karahanna, 2009; Tallon, 2007, 2009; Teo and Ang, 2001). Business and IT that positively aligns leads to achieving improved organizational performance and competitive advantage (Byrd et al., 2006; Duhan, 2007; Earl, 1993; Hung et al., 2016; Ilmudeen et al., 2019; Lee et al., 2008; Merali et al., 2012; Őri, 2018; Reich and Benbasat, 2000; Schwarz et al., 2010; Tai et al., 2019; Tallon, 2009). Thus, business and IT alignment is a critical component for successful SISP.

\subsection{The Outcome of SISP Success}

SISP success based on improved business and IT alignment enables organizations to facilitate business value and their competitive position by improving and sustaining capabilities and flexibility of key business and IT processes (Arvidsson et al., 2014; Duhan, 2007; Liang et al., 2017; Peppard and Ward, 2004; Preston and Karahanna, 2009; Tallon, 2007, 2009). Therefore, the outcome of SISP success in organizations is closely associated with delivering improved organizational capabilities and IT infrastructure flexibility.

\subsubsection{Organizational Capabilities}

Prior literature (Peppard and Ward, 2004; Peppard et al., 2014; Segars and Grover, 1998) has claimed that successful outcomes from SISP encourages organizations to improve overall capabilities such as problem identification, environmental scanning, and an ability to react to change (Duhan, 2009; Earl, 1993; Grant et al., 2010; Merali et al., 2012). Organizational capabilities refer to a firm's capacity to combine and deploy resources, including financial and physical assets (i.e., property, plant and equipment, and human capital), knowhow and information-based processes of the firm to gain the desired goal and sustained competitive advantage (Amit and Schoemaker, 1993). Organizational capabilities from earlier IS/IT related literature demonstrates the progress of organizational knowledge and processes (Doherty and Terry, 2009; Grant et al., 2010; Reich and Benbasat, 2000) as well as the interaction and optimization of business-IT investment and resources (Duhan, 2007; Grover and Segars, 2005; Merali et al., 2012; Peppard et al., 2014; Tai et al., 2019). In addition, Arvidsson et al. (2014), Őri (2018) and Tai et al. (2019) have discussed that business and IT alignment with a strategic objective encourages organizations to fulfill successful SISP by improving overall capabilities that the organization is keen to achieve. This indicates that SISP's success by aligning business strategies with IT strategies is anticipated to improve organizational capability. Based on the above argument, the following hypothesis is proposed.

Hypothesis 6: $\quad$ SISP's success has a positive effect on improving organizational capabilities.

\subsubsection{IT Infrastructure Flexibility}

IT infrastructure flexibility is defined as the ability of IT infrastructure, including hardware, software, networks, technical skills and IT adaptability to easily and quickly scale and evolve in accordance with the needs of the market (Byrd and Turner, 2000) and to generate tighter fit between business and IT strategy (Tallon, 2009). Roberts and Grover (2012) have identified that an organization's IT infrastructure allows it to perceive and 
respond to customer needs and requirements effectively, thus enhancing its agility. A flexible IT infrastructure enables organizations to link with business affiliates easily and allow organizations to proactively and quickly utilize informational resources, such as IS/IT applications and tools, thereby improve synergy between business and IT (Ravichandran, 2018).

Efficient planning of IT and business processes enables organizations to flexibly structure their IT infrastructure to effectively prepare for environmental changes occurring inside and outside the company and create IT based business innovation (Ravichandran, 2018). SISP success enables organizations to improve the flexibility of their IT infrastructure (Eisenhardt and Martin, 2000; Palanisamy, 2005; Tallon, 2009). Zwass (2009) has also argued that it is critical for organizations to recognize that IT infrastructure needs to be planned with flexibility at the planning stage to support business operation efficiency. Organizations with flexible IT infrastructure are able to secure both diversity in strategic responses and rapid shifts from one strategy to another (Eisenhardt and Martin, 2000; Govuzela and Mafini, 2019; Palanisamy, 2005) through considering internal and external business-IT environments (Kearns and Lederer, 2003; Peppard and Ward, 2016). Thus, a flexible IT infrastructure also enables organizations to connect with business affiliates easily and allows effective utilization of informational resources and tools (Griffith, 2011; Ravichandran, 2018; Shao, 2019).

The key SISP objective of organizations is particularly to merge speed with flexibility by reacting swiftly to changing business drivers to capture strategic results (Lutchman, 2012; McNurlin et al., 2009). Based on the attainment of IT infrastructure flexibility in SISP, increased change and uncertainty in organizations will be decreased, and the risks of being hampered by rigidity minimized. It will transform IT into an enabler of change rather than an inhibitor (Tallon, 2009). Furthermore, there is a positive relationship between IT infrastructure flexibility and business and IT alignment with successful SISP (Arvidsson et al., 2014; Jorfi et al., 2017; Ravichandran, 2018; Tallon, 2009). The construction of the IT infrastructure based on business and IT alignment quickly adapts to rapid business and IT changes as well as enables effective management of corporate IT assets and the creation of long-term business value (Griffith, 2011; Govuzela and Mafini, 2019; Ilmudeen et al., 2019; Liang et al., 2017; Shao, 2019). Therefore, the following hypothesis is proposed:

Hypothesis 7: SISP's success has a positive effect on improving IT infrastructure flexibility.

\section{Research Model}

From the literature review discussed above, this study proposes a research model to illustrate and test the relationship between facilitators and the outcome of SISP success as presented in Figure 1.

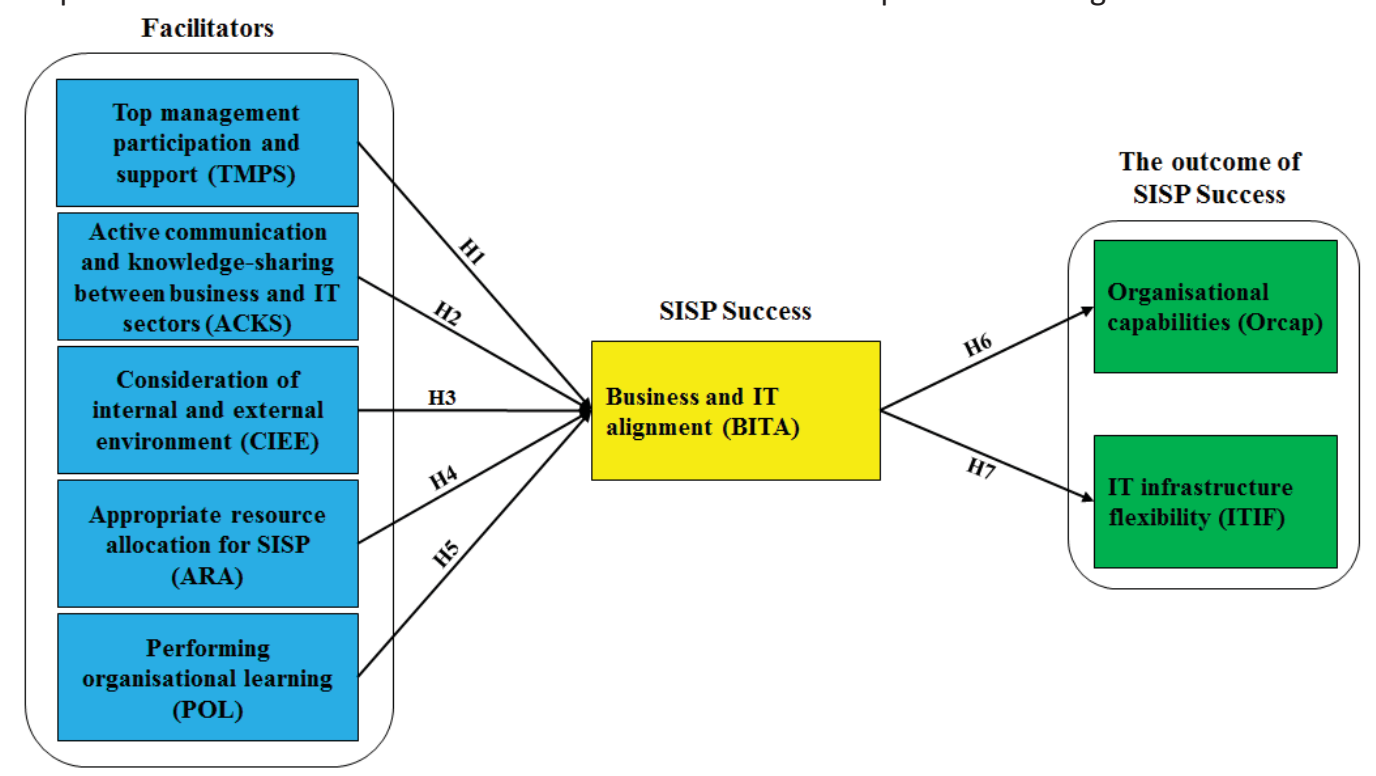

Figure 1: The Research Model

Consideration of the examined facilitators enables organizations to conduct SISP successfully. The more organizations consider potential facilitators, the greater likelihood they will realize SISP success through attaining business and IT alignment. Thus, the hypotheses 1 to 5 are proposed and each hypothesis has a positive 
effect upon business and IT alignment that is the dimension of SISP success. If organizations undertake SISP successfully, they are more likely to facilitate capabilities of business and IT processes and structures by adequately combining, optimizing and renewing them (Duhan, 2007; Grant et al., 2010; Merali et al., 2012; Peppard et al., 2014). SISP success also enables organizations to realize the flexibility of IT infrastructure for securing diversity in strategic responses as well as for reacting and responding swiftly for strategic results (Arvidsson et al., 2014; Lutchman, 2012; McNurlin et al., 2009; Palanisamy, 2005; Ravichandran, 2018). Based on the successful outcome of SISP, organizations are more likely to facilitate organizational performance and enhance their competitive advantage (Avison et al., 2004; Byrd et al., 2006; Hung et al., 2016; Lee et al., 2008; Merali et al., 2012; Peppard et al., 2014; Peppard and Ward, 2016).

\section{Research Methodology}

This paper identifies facilitators for achieving successful SISP and their impact as well as investigates the relationship between SISP facilitators and the outcome of SISP success. This study employs a positivist quantitative study with data collection achieved via a survey and statistical analysis of data to answer the research questions, test the hypotheses, and validate the research model. There are two main reasons for adopting the quantitative approach. First, a quantitative approach tests the relationship between variables with the use of numeric data. Second, the quantitative approach allows collecting data from a larger sample to be able to generalize the results of testing the proposed theories to a larger population (Creswell, 2009; Hair et al., 2010).

The quantitative data analysis is Structural Equation Modelling (SEM) via AMOS, which is regarded as a family of statistical techniques allowing the researchers to test multivariate models by the analysis of covariance structures (Anderson and Gerbing, 1988; Hair et al., 2010). SEM is appropriate for data analysis in this study for several reasons. Firstly, SEM allows researchers to hypothesize a research framework with a series of causal relationships among multiple variables and to validate such relationships at the same time. Secondly, SEM can estimate the relationship between the latent variables that are available in the research model (Hair et al., 2010). Therefore, based on the SEM analysis, the relationship between SISP facilitators and the outcome of SISP succesS is analyzed.

The survey instrument was designed to collect data from business managers and IT managers who have experience with SISP in large South Korean organizations. Further, according to a number of government reports in South Korea (NIA, 2017; NIPA, 2012), there are gaps between large to small and medium enterprises (SMEs) in the overall level of IT diffusion and use, SISP introduction, IT investment, along with the scale of IT departments and $\mathrm{CIO}$ positions.

The sample for the survey consisted of the 'top 1000 company ranking' in South Korea based on total sales and assets from the database of KORCHAMBIZ, which is managed by the Korea Chamber of Commerce and Industry $(\mathrm{KCCl})$. The survey tool was made up of questions with a five-point Likert scale to establish the importance of each issue. The questionnaire was translated from English into Korean to ensure South Korean respondents understood the questions easily to be able to respond (Douglas and Craig, 2007).

Before the main survey, a pilot study was undertaken with 13 managers from eight South Korean organizations. It helped confirm the internal consistency of the measuring instrument ensuing Cronbach's Alpha test. The alpha value between 0.8 and 0.9 is normally considered as a high level of reliability (Hair et al., 2010). The alpha for all constructs was more than 0.8 as presented in Table 2, which confirmed that the internal reliability of the questionnaire was acceptable and reliable for distributing for the main survey and conducting further statistical analysis. 
Table 2: The Reliability Test Result using Cronbach's Alpha

\begin{tabular}{|c|c|c|c|}
\hline Constructs & No. of Items & Means & Cronbach's Alpha \\
\hline TMPS & 6 & 3.567 & .853 \\
\hline ACKS & 7 & 3.514 & .889 \\
\hline CIEE & 4 & 3.275 & .840 \\
\hline ARA & 4 & 3.375 & .851 \\
\hline POL & 5 & 3.220 & .887 \\
\hline BITA & 5 & 3.550 & .913 \\
\hline Orcap & 7 & 3.513 & .890 \\
\hline ITIF & 6 & 3.383 & .857 \\
\hline
\end{tabular}

The translated questionnaire with survey description was then printed out and forwarded by post to business and IT managers in 700 organizations. A total of 250 responses (118 business managers and 132 IT managers) were received with a response rate of $35.7 \%$. The highest percentage of the respondents' industry was manufacturing (55.4\%), followed by banking, finance and insurance (8.8\%), construction (7.2\%), cargo, logistics, and transport (5.6\%), electricity, electronics, IT and telecommunications (8.4\%), services (7.6\%) and wholesale and retail trade (8\%) as shown in Figure 2 . The collected data was stored and screened by using SPSS statistics for addressing the missing values, outliers, kurtosis and skewness.
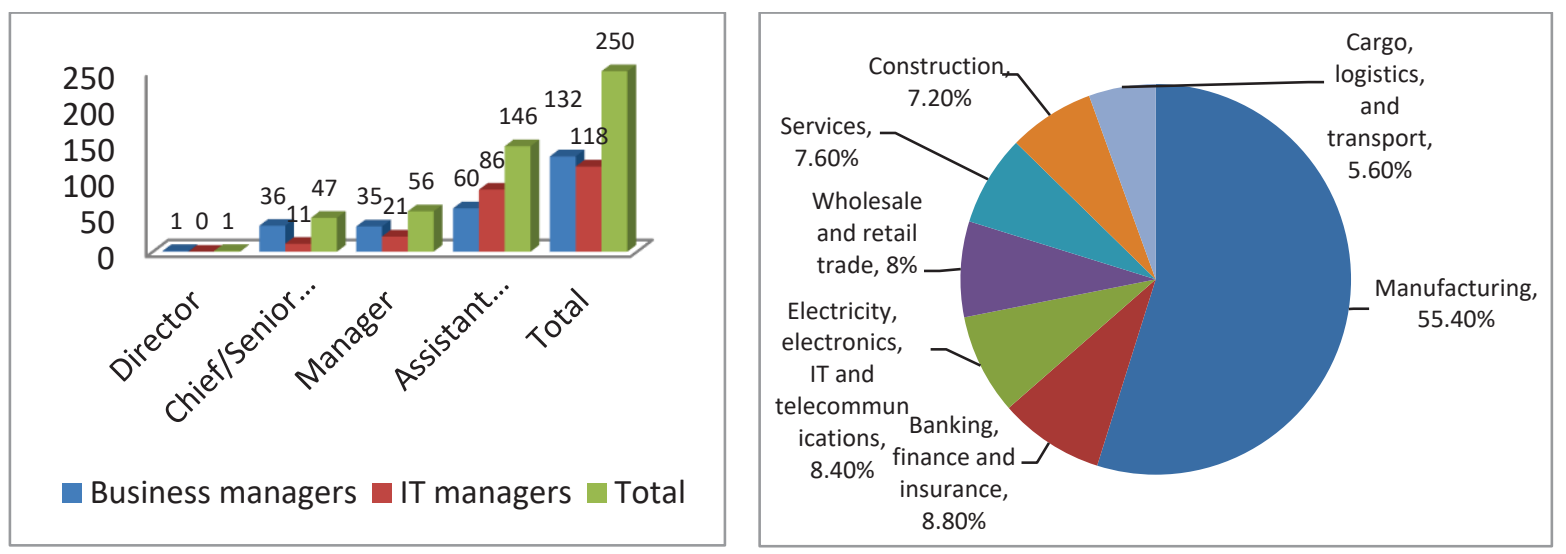

Figure 2: The Summary of the Survey Respondents', Positions and Industries that Participated

\section{Data Analysis and Results}

The SEM analysis is commonly conducted in two steps, namely, developing and validating a measurement model as well as testing and validating a structural model (Hair et al., 2010). SEM uses confirmatory factor analysis (CFA) for assessing the measurement model. Assessing the measurement model by using CFA examines how well the measurement variable used to measure the theoretical constructs represent the theoretical construct (Hair et al., 2010). Before the CFA, exploratory factor analysis (EFA) all research constructs were satisfied with the applicability criteria (the Kaiser-Meyer-Olkin measure of Sampling Adequacy (KMOMSA) was more than 0.90, Bartlett's Test of Sphericity (BTOS) was 0 and Eigenvalues was greater than 1.

In the CFA, a one-factor congeneric model for each construct was first conducted to investigate and specify the fitness of the full measurement model. The overall fitness of the measurement model is then assessed via goodness-of-fit (GOF) indices. In this study, the Normed chi-square ( $\chi 2 / d f)$, the goodness of fit index (GFI), the comparative fit index (CFI), the Tucker-Lewis Index (TLI), the Root mean square error of approximation (RMSEA) and the Standardized RMR (SRMR) were used for assessing the fitness of the congeneric model, following the recommendation of Hair et al. (2010). If the congeneric model does not properly meet the requirements, respecifying the congeneric measurement model to improve the fitness was undertaken by the consideration of the standard factor loading (SFL) of each item of the measurement variables, standard residuals and modification indices (Hair et al., 2010). Following this criterion, a few measurement items were deleted from the congeneric models. The constructs of the full measurement model were then modified to reflect the modifications done in those congeneric measurement models. 
To determine the cause of the misfit, the standardized residual covariance and the modification indices were scrutinized for the constructs. Based on the re-examination and re-specification of the constructs based on the standardized residual covariance and the modification indices, one item in the TMPS, ACKS, POL, BITA, Orcap, and ITIF construct was deleted, and the residuals of the eCIEE1 and eCIEE2, and eARA1 and eARA3 were correlated. After that, the GOF statistics values on one factor congeneric model of all constructs were satisfied with the acceptable ranges as shown in Table 3.

Table 3: Goodness-of-fit Results for the Final Measurement Models

\begin{tabular}{|l|c|c|c|c|c|c|}
\hline Construct (deleted item(s)) & $\chi^{2} / \mathbf{d f}$ & GFI & CFI & TLI & RMSEA & SRMR \\
\hline TMPS (TMPS item 2 deleted) & 1.231 & 0.991 & 0.998 & 0.996 & 0.030 & 0.0167 \\
\hline ACKS (ACKS item 6 deleted) & 2.396 & 0.972 & 0.983 & 0.971 & 0.075 & 0.0277 \\
\hline CIEE (no deletion by using MI) & 0.054 & 1.000 & 1.000 & 1.008 & 0.000 & 0.0011 \\
\hline ARA (no deletion by using MI) & 0.007 & 1.000 & 1.000 & 1.010 & 0.000 & 0.0006 \\
\hline POL (POL item 4 deleted) & 1.235 & 0.995 & 0.999 & 0.996 & 0.031 & 0.0152 \\
\hline BITA (BITA item 1 deleted) & 0.144 & 0.999 & 1.000 & 1.020 & 0.000 & 0.0057 \\
\hline Orcap (Orcap item 1 deleted) & 2.302 & 0.974 & 0.980 & 0.967 & 0.072 & 0.0295 \\
\hline ITIF (ITIF item 2 deleted) & 1.533 & 0.988 & 0.994 & 0.988 & 0.046 & 0.0232 \\
\hline Recommended value & $<3.00$ & $>0.95$ & $>0.95$ & $>0.95$ & $<0.08$ & $<0.08$ \\
\hline
\end{tabular}

The convergent validity and the discriminant validity of the constructs were then calculated. The convergent validity is first undertaken to determine the degree to which the indicators of a construct converge. Three estimates, namely, the standardized factor loading (SFL), the average variance extracted (AVE), and the construct reliability (CR), were used to measure the convergent validity (Hair et al., 2010). The CR of 0.7 or higher of a construct is normally the acceptable value and an SFL of 0.6 or higher of an item indicates that the item converges on the construct (Hair et al., 2010). The CR and SFL value of all items in this study were above 0.7 and 0.6 , thus they are considered as having convergent validity (Hair et al., 2010). According to a rule of thumb, the AVE of a construct should be at 0.5 or more to have a higher convergence (Hair et al., 2010). The convergent validity measures for the final constructs measured using CRs and AVEs are shown in Table 4. The Cronbach's Alpha for the constructs was also above 0.7 (the lowest Alpha value was 0.783 in BITSA), so the reliability of the instrument is adequate.

Table 4: Convergent Validity of the Constructs of the Final Measurement Model

\begin{tabular}{|c|c|c|c|c|c|}
\hline Constructs & CR & AVE & No of items & Items left & Cronbach's Alpha \\
\hline TMPS & 0.916 & 0.687 & 6 & 5 & 0.884 \\
\hline ACKS & 0.934 & 0.704 & 7 & 6 & 0.887 \\
\hline CIEE & 0.934 & 0.780 & 4 & 4 & 0.910 \\
\hline ARA & 0.939 & 0.793 & 4 & 4 & 0.828 \\
\hline POL & 0.886 & 0.662 & 5 & 4 & 0.901 \\
\hline BITA & 0.886 & 0.661 & 5 & 4 & 0.783 \\
\hline Orcap & 0.933 & 0.666 & 7 & 6 & 0.871 \\
\hline ITIF & 0.908 & 0.664 & 6 & 5 & 0.844 \\
\hline
\end{tabular}

The discriminant validity is then conducted to determine the distinction of the constructs from each other (Hair et al., 2010). The discriminant validity between the two constructs is determined by comparing the squared correlation between the constructs with the average variance extracted (AVE). According to Hair et al. (2010), the AVE of the constructs should be higher than the squared correlation for adequate discriminant validity. A summary of the discriminant validity of the constructs in the final measurement is described in Table 5. 
Table 5: Discriminant Validity of the Constructs in the Final Measurement Model (*: AVE value)

\begin{tabular}{|c|c|c|c|c|c|c|c|c|}
\hline & TMPS & ACKS & CIEE & ARA & POL & BITA & Orcap & ITIF \\
\hline TMPS & $\mathbf{0 . 6 8 7 ^ { * }}$ & & & & & & & \\
\hline ACKS & 0.320 & $\mathbf{0 . 7 0 4 ^ { * }}$ & & & & & & \\
\hline CIEE & 0.285 & 0.350 & $\mathbf{0 . 7 8 0 *}$ & & & & & \\
\hline ARA & 0.358 & 0.436 & 0.436 & $\mathbf{0 . 7 9 3 ^ { * }}$ & & & & \\
\hline POL & 0.341 & 0.454 & 0.506 & 0.601 & $\mathbf{0 . 6 6 2 *}$ & & & \\
\hline BITA & 0.181 & 0.240 & 0.230 & 0.205 & 0.188 & $\mathbf{0 . 6 6 1 *}$ & & \\
\hline Orcap & 0.439 & 0.264 & 0.158 & 0.204 & 0.241 & 0.491 & $\mathbf{0 . 6 6 6 *}$ & \\
\hline ITIF & 0.252 & 0.249 & 0.212 & 0.228 & 0.245 & 0.442 & 0.598 & $\mathbf{0 . 6 6 4}$ \\
\hline
\end{tabular}

By assessing the measurement model and obtaining an appropriate fitness of the measurement model, the structural model was developed and measured to test the proposed hypotheses and to reveal whether the dependence relationships specified in the model between constructs are valid (Hair et al., 2010) as presented in Figure 3. As shown in Table 6, the evaluation of the structural model reveals that $\mathrm{H} 1, \mathrm{H} 2, \mathrm{H} 3, \mathrm{H} 6, \mathrm{H} 7$ (shown in Bold) were supported. There is a hypothesis ( $\mathrm{H} 4$ which is shown in italic with bold) that were a little out of the recommended acceptable range, but it was supported in $\mathrm{p}<0.1$ level. However, H5 was not supported.

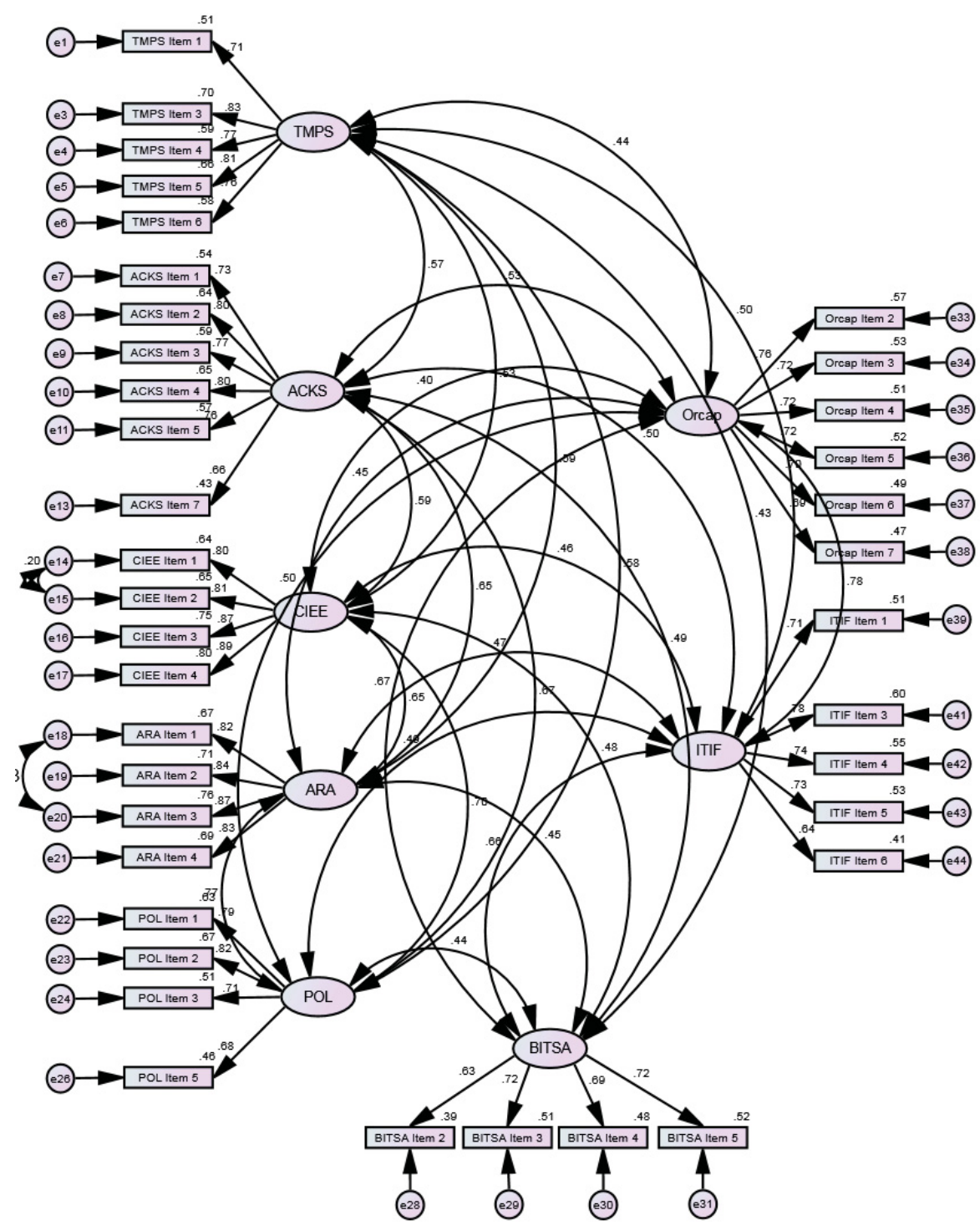




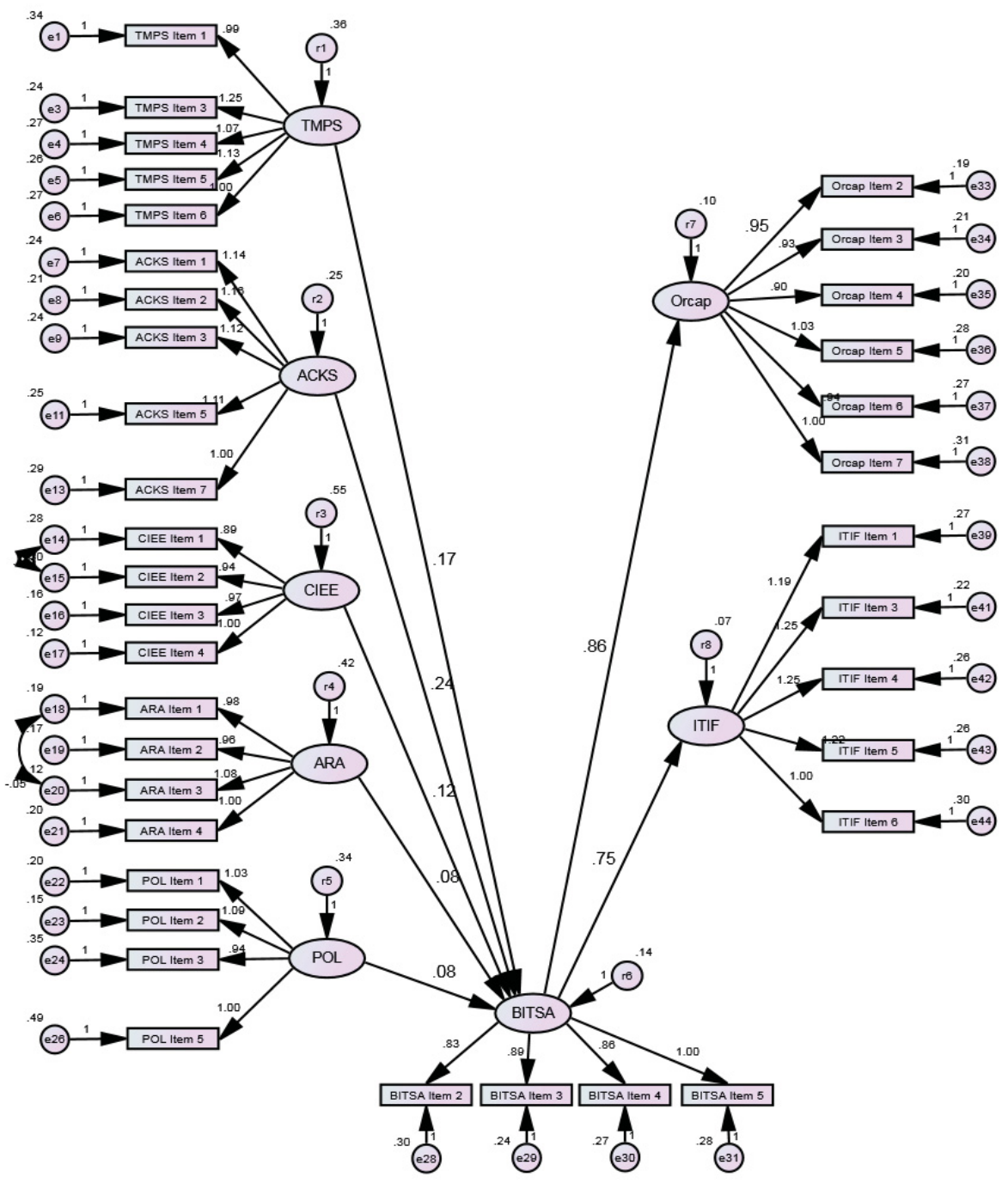

Figure 3: The Final CFA Measurement Model (Top) and the Structural Model (Down)

Table 6: The Result of Hypothesis Testing in the Structural Model

\begin{tabular}{|c|c|c|c|c|c|}
\hline Hypothesis & Estimate & S.E & $p$-value & Support? & \multirow{8}{*}{$\begin{array}{c}* * * \text { indicates } \mathrm{p}<0.01 \\
* * \text { indicates } \mathrm{p}<0.05 \\
* \text { indicates } \mathrm{p}<0.1\end{array}$} \\
\hline $\mathrm{H} 1$ & .165 & .052 & $.001 * * *$ & $Y$ & \\
\hline $\mathrm{H} 2$ & .236 & .065 & $* * *$ & $Y$ & \\
\hline $\mathrm{H} 3$ & .121 & .040 & $.003 * * *$ & $Y$ & \\
\hline $\mathrm{H} 4$ & .081 & .045 & $.073 *$ & Yes $p<0.1$ & \\
\hline H5 & .082 & .052 & .115 & $N$ & \\
\hline $\mathrm{H} 6$ & .862 & .123 & $* * *$ & $Y$ & \\
\hline $\mathrm{H} 7$ & .746 & .111 & $* * *$ & $Y$ & \\
\hline
\end{tabular}

According to the result of the structural model, H1 (TMPS), H2 (ACKS), H3 (CIEE) and H4 (ARA) were facilitators that have a positive effect upon BITA with path coefficients of $0.165(p<0.01), 0.236(p<0.01), 0.121(p<0.01)$ and $0.081(p<0.1)$ respectively. This indicates that TMPS, ACKS and CIEE were significant at a $99 \%$ confidence interval, and ARA was significant at a $90 \%$ confidence interval. BITA as a dimension of SISP success also had a positive influence upon both Orcap (H6) and ITIF (H7) with path coefficients of $0.862(p<0.01)$ and $0.746(p<0.01)$, which were significant at a $99 \%$ confidence interval. Figure 4 shows the relationship between facilitators and the outcome of their success. 


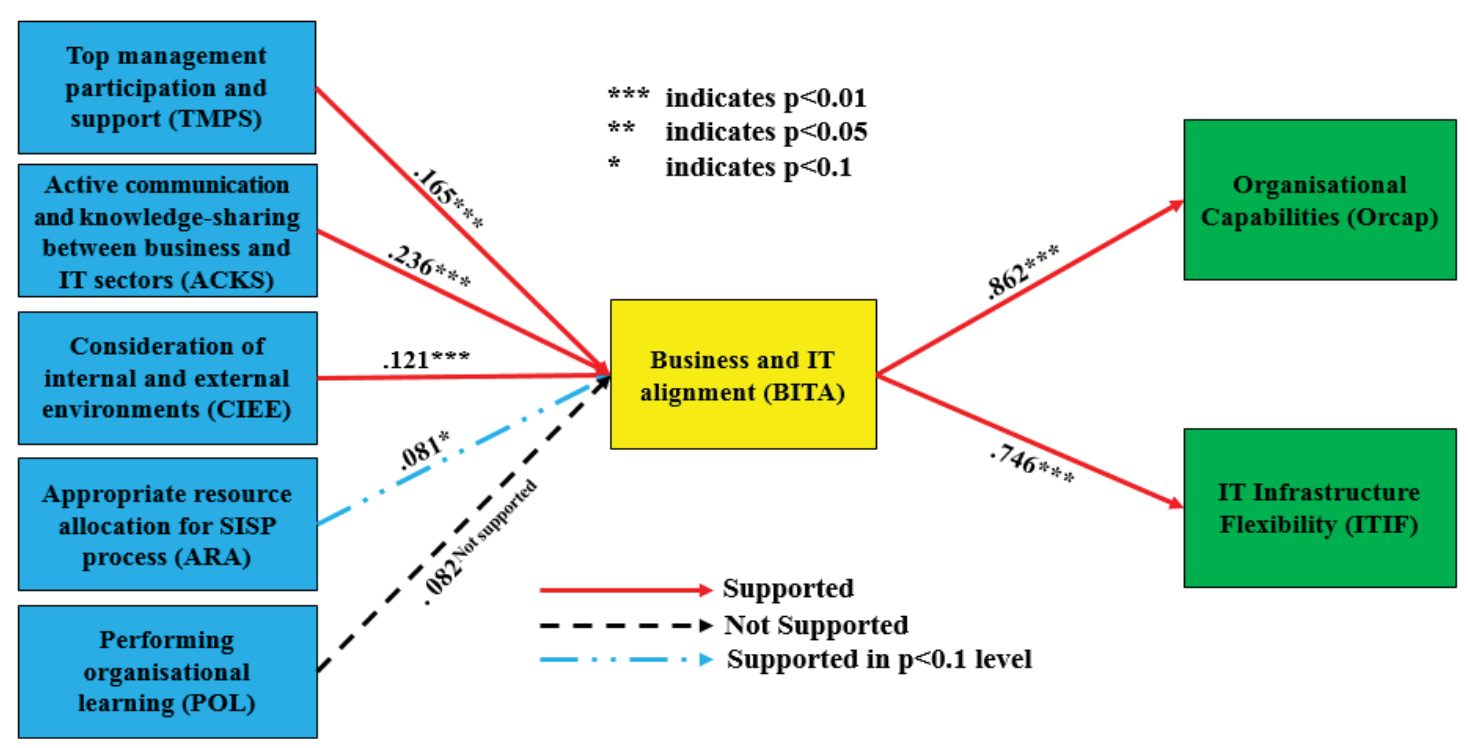

Figure 4: The Result of the Hypothesized Structural Model

\section{Discussion of Findings}

This study found that top management participation and support ( $p$-value of $.001 * * *$ ), active communication and knowledge-sharing between business sectors and IT sectors ( $p$-value of $* * *$ ), consideration of internal and external environments ( $p$-value of .003***) and appropriate resource allocation for SISP ( $p$-value of .073*) are important facilitators that lead to realizing SISP success by improving the level of business and IT alignment in South Korean organizations. We confirmed the argument discussed by Peppard and Ward (2016) and Wallace (2013) that SISP's success is associated with a function of various factors.

Through the survey, we identified four factors as facilitators, including top management participation and support (Ali et al., 2018; Gopalakrishna-Remani et al., 2019; Kearns, 2006; Shao, 2019; Teubner, 2013); active communication and knowledge sharing between business and IT sectors (Arvidsson et al., 2014; Carrillo et al., 2019; Philip, 2009; Yeh et al., 2011); consideration of internal and external environments (Chi et al., 2005; Hung et al., 2016; Mirchandani and Lederer, 2012; Newkirk et al., 2008), and adequate resource allocation for SISP (Lientz, 2010; Samaha and Baki, 2009; Wallace, 2013). In addition, we confirmed that the four facilitators have a positive effect on business and IT alignment. This indicates that SISP's success based on improved business and alignment depends on how much top management participate, understand and support the SISP process (Elbanna, 2013; Kearns, 2006; Kitsios and Kamariotou, 2019b; Philip, 2009). Further, it depends on how actively internal members in an organization communicate and share their knowledge and opinions with each other (Gutierrez et al., 2009; Maharaj and Brown, 2015; Pai, 2006).

We identified the importance of considering internal and external environments as well as allocating appropriate resources to fulfill business and IT alignment for SISP success in South Korean organizations. This finding is in line with the extant literature where considering internal and external environments (Chi et al., 2005; Globocnik et al., 2020; Kamariotou and Kitsios, 2019b; King, 2009; Newkirk et al., 2008; Ravichandran, 2018; Sabherwal et al., 2019) and adequate resources allocation (Cassidy, 2006; Jorfi et al., 2017; Newkirk and Lederer, 2007; Peppard and Ward, 2016; Spil et al., 2010; Teubner, 2013) during SISP helps organizations better fulfill business and IT alignment. This suggests that the more South Korean organizations recognize the importance of internal and external environmental factors during SISP, the more likely they will realize improved levels of business and IT alignment.

However, we found from the survey that performing organizational learning is not a facilitator that positively influenced business and IT alignment in South Korean organizations ( $p$-value of .115). This finding is in contrast with the IS/IT literature that has claimed organizational learning performed during SISP has a positive effect on SISP success (Merali et al., 2012; Newkirk and Lederer, 2007; Otim et al., 2009; Pai, 2006). Although organizational learning has continued to be a focus in SISP studies, an assessment of its success based on its impact has not been addressed in the studies on SISP (Otim et al., 2009; Peppard and Ward, 2004). The reason might be inferred from top management's poor understanding on the strategic use of IS/IT and the lack of human 
resources who deal with long-term IT planning in the recent research conducted by NIA (2019). Another possible reason might be that there is no learning process related to SISP in the organization, or that learning / training is not compulsory for employees. In addition, although there is a communication and knowledge-sharing in the business and IT departments during SISP, their passive attitude and lack of interest in the learning and the rigidity of the organizational culture may be a contributor. The inference is supported by a research result of Park and Kim (2018) that there is a positive relationship between a knowledge-sharing behavior and climate and organizational learning. The behavior and climate on knowledge-sharing are considered as an antecedent to ultimately promote organizational learning. Therefore, it is suggested that further research of this issue be undertaken in the future.

Through the analysis, we identified that SISP success based on business and IT alignment turns out to be a dimension that has a positive effect upon the outcome of SISP success by improving both organizational capabilities ( $\mathrm{p}$-value of $* * *$ ) and IT infrastructure flexibility ( $\mathrm{p}$-value of $* * *)$. This finding is in line with the research of Arvidsson et al. (2014), Duhan (2007), Merali et al. (2012), and Peppard et al. (2014), that business and IT alignment encourages optimizing organizational knowledge and business-IT resources and transforming business process to ultimately enhance business outcomes. Grant et al. (2010) also argued that business and IT alignment is an essential factor for contemporary organizations to effectively deal with dynamic and rapidly changing environments and maintaining their vision and strategic objectives. Further, the significant direct influence of the business and IT alignment on IT infrastructure flexibility in the outcome of SISP success is consistent with previous studies (Jorfi et al., 2017; Ilmudeen et al., 2019; McNurlin et al., 2009; Tai et al., 2019; Tallon, 2009; Zwass, 2009).

Business and IT alignment provides IT infrastructure flexibility for ensuring strategic flexibility through responding rapidly to changes and trends of the marketplace (Govuzela and Mafini, 2019; Kearns and Lederer, 2003; Liang et al., 2017; Palanisamy, 2005; Peppard and Ward, 2016). Arvidsson et al. (2014), Ravichandran (2018) and Tallon (2009) have discussed that there is a profound influence on the link between business and IT alignment and IT infrastructure flexibility. This result suggests that if business and IT alignment is effectively attained by the consideration of various facilitators in South Korean organizations, they are more likely to implement and use their IS/IT systems successfully. Hence, to improve the level of the outcome of SISP success, organizations need to focus more on considering how they will align their business and IT objectives, plans and strategies. Table 7 below summarizes the relationship among facilitators, SISP success, and the outcome of SISP success indicated in Figure 4.

Table 7: The Summary of the Relationship among the Three Constructs

\begin{tabular}{|l|l|l|l|l|}
\hline \multicolumn{1}{|c|}{ Facilitators } & SISP success & & \multicolumn{1}{|c|}{ The outcome of SISP success } \\
\hline $\begin{array}{l}\text { Top management participation and } \\
\text { support (TMPS) }\end{array}$ & & & \\
$\begin{array}{l}\text { Active communication and } \\
\text { knowledge-sharing between } \\
\text { business and IT sector (ACKS) } \\
\begin{array}{l}\text { Consideration of internal and } \\
\text { external environment (CIEE) } \\
\text { Appropriate resource allocation } \\
\text { (ARA) }\end{array}\end{array}$ & $\rightarrow$ & $\begin{array}{l}\text { Business and IT } \\
\text { alignment (BITA) }\end{array}$ & $\rightarrow$ & $\begin{array}{l}\text { Organizational capabilities } \\
\text { (Orcap) } \\
\text { IT infrastructure flexibility } \\
\text { (ITIF) }\end{array}$ \\
\hline
\end{tabular}

\section{Conclusion}

IS/IT is a critical requirement for all aspects of business operations in today's highly dynamic environment. The need for SISP is essential for all contemporary organizations to provide a road map and to realize the expected benefits from their IT investment. Within this context, understanding the necessity of SISP facilitators for improving SISP success and its better outcome is a primary concern. Despite a high diffusion and use level of advanced IS/IT systems in South Korean organizations, successful IS/IT implementation, remains low.

This paper examined facilitators vital for the SISP process and observed the relationship among these facilitators; SISP success, and the outcome of SISP success. Based on the survey analysis in 250 South Korean organizations, the study undertaken shows that there are various facilitators that enable organizations to attain SISP success based on improved business and IT alignment. We also identify that SISP success with business and IT alignment has a positive effect upon improving organizational capabilities and IT infrastructure flexibility. Through the 
results of this study, we identify that there is a causal relationship among SISP facilitators, SISP success, and the outcome of SISP success.

We suggest three implications of this study. First, various facilitators are important to achieve a better quality of SISP success and hence improved business and IT alignment. Second, there have been few studies that empirically observe how SISP success affects its outcome. We classify two dimensions that lead to better outcomes, such as organizational capabilities and IT infrastructure flexibility, and identify that there is a positive relationship between SISP success and the outcome of SISP success. Finally, this study confirms the causal relationship among facilitators, SISP success, and its outcomes in South Korean organizations.

The research from this paper contributes to the existing literature from both a theoretical perspective and a practical one. Most prior literature sources have discussed a relationship between one or some important factor(s) and SISP success. However, we identify various facilitators that need to be considered in organizations and extend the research framework to observe the relationship between facilitators, SISP success, and the outcome of SISP success. Hence, this study theoretically and practically suggests the importance of considering SISP facilitators, and their causal relationship on business outcomes.

The current study concentrated only on examining the relationship among facilitators, SISP success, and the outcome of SISP success in large organizations of South Korea. However, the relationship between large organizations and small to medium-size enterprises may present some differences. Likewise, the relationship perspectives may differ from business sectors and IT sectors, thus its investigation could be suggested as future research.

\section{References}

Ahmed, Y. A., Ahmad, M. N., Ahmad, N., and Zakaria, N. H. 2019. Social media for knowledge-sharing: A systematic literature review. Telematics and Informatics, 37, pp. 72-112.

Al Nahyan, M. T., Sohal, A., Hawas, Y., and Fildes, B. 2019. Communication, coordination, decision-making and knowledgesharing: a case study in construction management. Journal of Knowledge Management, 23(9), pp. 1764-1781.

Ali, R. H. R. M., Mohamad, R., Talib, Y. Y. A., and Abdullah, A. 2018. The roles of top management and users in strategic IS planning: a perspective of SMEs. International Journal of Information Systems and Project Management, 6(4), pp. 6180.

Amit, R., and Schoemaker, P. H. 1993. Strategic assets and organizational rent. Strategy Management Journal, 14(1), pp. 33-46.

Amrollahi, A., Ghapanchi, A. H., and Talaei-Khoei, A. 2013. A systematic literature review on strategic information systems planning: Insights from the past decade. Pacific Asia Journal of the Association for Information Systems, 5(2), pp.1-28.

Anderson, J. C., and Gerbing, D. W. 1988. Structural equation modeling in practice: A review and recommend two-step approach. Psychological Bulletin, 5(2), pp. 411-423.

Argote, L., and Miron-Spektor, E. 2011. Organizational learning: from experience to knowledge. Organizational Science, 22(5), pp.1123-1137.

Arvidsson, V., Holmström, J., and Lyytinen, K. 2014. Information systems use as strategy practice: A multi-dimensional view of strategic information system implementation and use. The Journal of Strategic Information Systems, 23(1), pp. 4561.

Ateş, N. Y., Tarakci, M., Porck, J. P., van Knippenberg, D., and Groenen, P. J. 2020. The dark side of visionary leadership in strategy implementation: Strategic alignment, strategic consensus, and commitment. Journal of Management, 46(5), pp. 637-665.

Bechor, T., Neumann, S., Zviran, M., and Glezer, C. 2010. A contingency model for estimating success of strategic information systems planning. Information and Management, 47(1), pp. 17-29.

Beynon-Davies, P. (2020). Business information systems. London, UK, Red Globe Press.

Bhatt, G. D. (2009). The role of dynamic organizational compatibilities in creating, renewing, and leveraging information systems competencies. In: W. R. King, ed. Planning for Information Systems Advances in Management Information Systems, Volume 14. Armonk, NY, USA: M.E. Sharpe, Inc. pp. 96-107.

Byrd, T. A., Lewis, B. R., and Bryan, R. W. 2006. The leveraging influence of strategic alignment on IT investment: An empirical examination. Information and Management, 43(3), pp. 308-321.

Byrd, T. A., and Turner, D. E. 2000. Measuring the flexibility of information technology infrastructure: exploratory analysis of a construct. Journal of Management Information Systems, 17(1), pp. 167-208.

Cassidy, A. 2006. A Practical Guide to Information Systems Strategic Planning. $2^{\text {nd }}$ edition, Florida, USA, Taylor and Francis Group: CRC Press.

Carrillo, F. J., Edvardsson, B., Reynoso, J., and Maravillo, E. 2019. Alignment of resources, actors and contexts for value creation. International Journal of Quality and Service Sciences, 11(3), pp. 424-438.

Chi, L., Jones, K. G., Lederer, A. L., Li, P., Newkirk, H. E., and Sethi, V. 2005. Environmental assessment in strategic information systems planning. International Journal of Information Management, 25(3), pp. 253-269. 
Choi, S., and Bae, S. 2007. Strategic information systems selection with incomplete preferences: A case of Korean electronics company. Journal of the Operational Research Society, 60(2), pp. 180-190.

Creswell, J. W. 2009. Research Design: Qualitative, Quantitative, and Mixed Methods Approaches. $3^{\text {rd }}$ ed. California, USA, Thousand Oaks: Sage publications, Inc.

Doherty, N. F., and Terry, M. 2009. The role of IS capabilities in delivering sustainable improvements to competitive positioning. The Journal of Strategic Information Systems, 18(2), pp. 100-116.

Doherty, N. F., Marples, C. G., and Suhaimi, A. 1999. The relative success of alternative approaches to strategic information systems planning: an empirical analysis. Journal of Strategic Information Systems, 8(3), pp. 263-283.

Douglas, S. P., and Craig, C. S. 2007. Collaborative and iterative translation: an alternative approach to back translation. Journal of International Marketing, 15(1), pp. 30-43.

Duhan, S. 2007. A capabilities-based toolkit for strategic information systems planning in SMEs. International Journal of Information Management, 27(5), pp. 352-367.

Earl, M. J. 1993. Experiences in strategic information systems planning. MIS Quarterly, 17(1), pp. 1-24.

Eisenhardt, K. M., and Martin, J. A. 2000. Dynamic capabilities: what are they? Strategic Management Journal, 21(10-11), pp. 1105-1121.

Elbanna, A. 2013. Top management support in multiple-project environments: an in-practice view. European Journal of Information Systems, 22(3), pp. 278-294.

Gable, G. 2010. Strategic information systems research: an archival analysis. The Journal of Strategic Information Systems, 19(1), pp. 3-16.

García-Sánchez, E., Guerrero-Villegas, J., and Aguilera-Caracuel, J. 2019. How do technological skills improve reverse logistics? The moderating role of top management support in information technology use and innovativeness. Sustainability, 11(1), pp. 58-75.

Gerow, J. E., Grover, V., and Thatcher, J. 2016, Alignment's nomological network: theory and evaluation. Information \& Management, 53(5), pp. 541-553.

Globocnik, D., Faullant, R., and Parastuty, Z. 2020. Bridging strategic planning and business model management-A formal control framework to manage business model portfolios and dynamics. European Management Journal, 38(2), pp. 231-243.

Gopalakrishna-Remani, V., Jones, R. P., and Camp, K. M. 2019. Levels of EMR adoption in US hospitals: An empirical examination of absorptive capacity, institutional pressures, top management beliefs, and participation. Information Systems Frontiers, 21(6), pp. 1325-1344.

Gottschalk, P. 1999. Implementation predictors of strategic information systems plans. Information and Management, 36(2), pp. 77-91.

Gottschalk, P. 2007. Business Dynamics in Information Technology. Idea Group Publishing Inc., Hershey, PA.

Govuzela, S., and Mafini, C. 2019. Organizational agility, business best practices and the performance of small to medium enterprises in South Africa. South African Journal of Business Management, 50(1), pp. 1-13.

Grant, K., Hackney, R., and Edgar, D. 2010. Strategic Information Systems Management. Hampshire, UK: Cengage Leaning EMEA.

Gregory, R. W., Kaganer, E., Henfridsson, O. and Ruch, T. J. 2018. IT Consumerization and the Transformation of IT Governance. MIS Quarterly, 42(4), pp. 1225-1253.

Griffiths, P. 2011. Strategy-technology Alignment: Deriving Business Value from ICT. United Kingdom: Academic Conferences Limited.

Grover, V., and Segars, A. H. 2005. An empirical evaluation of stages of strategic information systems planning: patterns of process design and effectiveness. Information and Management, 42(5), pp. 761-779.

Gutierrez, A., Orozco, J., and Serrano, A. 2009. Factors affecting IT and business alignment: a comparative study in SMEs and large organizations. Journal of Enterprise Information Management, 22(1/2), pp. 197-211.

Hair, J. F., Black, W. C., Babin, B. J., Anderson, R. E., and Tatham, R. L. 2010. Multivariate Data Analysis. 7th ed. Upper Saddle River, NJ: Prentice Hall Inc.

Hatzakis, T., Lycett, M., Macredie, R. D., and Martin, V. A. 2005. Towards the development of a social capital approach to evaluating change management interventions. European Journal of Information Systems, 14(1), pp. 60-74.

Hong, P., and Hwang, W. 2011. Operational capabilities and performance toward global supply chain: An overview of Korean manufacturing and service firms. International Journal of Logistics Systems and Management, 8(2), pp. 183197.

Hung, S. Y., Huang, W. M., Yen, D. C., Chang, S. I., and Lu, C. C. 2016. Effect of information service competence and contextual factors on the effectiveness of strategic information systems planning in Hospitals. Journal of Global Information Management, 24(1), pp. 14-36.

Ilmudeen, A., Bao, Y., and Alharbi, I. M. 2019. How does business-IT strategic alignment dimension impact on organizational performance measures. Journal of Enterprise Information Management. 32(3), pp. 457-476.

Jorfi, S., Nor, K.M. and Najjar, L. 2017. An empirical study of the role of IT flexibility and IT capability in IT-business strategic alignment. Journal of Systems and Information Technology, 19(1/2), pp. 2-21.

Kamariotou, M., and Kitsios, F. 2019a. Strategic Information Systems Planning. In: M. Khosrow-Pour, D.B.A., ed. Advanced Methodologies and Technologies in Business Operations and Management USA: IGI Global. pp. 535-546.

Kamariotou, M., and Kitsios, F. 2019b. Strategic Planning and Information Systems Success: Evaluation in Greek SMEs. In: 2019 IEEE 21st Conference on Business Informatics (CBI). Moscow, Russia: IEEE. Vol. 1, pp. 204-211. 
Kannabiran, G., and Sundar, S. 2011. Relevance of information systems strategic planning practices in e-business contexts. Journal of Electronic Commerce in Organizations, 9(1), pp. 17-37.

Kappelman, L., McLean, E., Johnson, V., and Gerhart, N. 2014. The 2014 SIM IT key issues and trends study. MIS Quarterly Executive, 13(4), pp. 237-263.

Kappelman, L., Nguyen, Q., McLean, E., Maurer, C., Johnson, V., Snyder, M., and Torres, R. 2017. The 2016 SIM IT Issues and Trends Study. MIS Quarterly Executive, 16(1), pp. 47-80.

Karanja, E., and Patel, S. C. 2012. A review of research trends in strategic information-systems planning. International Journal of Business Information Systems,10(2), pp. 151-177.

Karpovsky, A., and Galliers, R. D. 2015. Aligning in practice: from current cases to a new agenda. Journal of Information Technology, 30(2), pp. 136-160.

Kearns, G. S. 2006. The effect of top management support of SISP on strategic IS management: insights from the US electric power industry. Omega, 34(3), pp. 236-253.

Kearns, G. S., and Lederer, A. L. 2000. The effect of strategic alignment on the use of IS-based resources for competitive advantage. Journal of Strategic Information Systems, 9(4), pp. 265-293.

Kearns, G. S., and Lederer, A. L. 2003. A resource-based view of strategic IT alignment: how knowledge sharing creates competitive advantage. Decision Sciences, 34(1), pp. 1-29.

Kearns, G. S., and Sabherwal, R. 2007. Antecedents and consequences of information systems planning integration. IEEE Transactions on Engineering Management, 54(4), pp. 628-643.

Kearns, G. S., and Sabherwal, R. 2007. Strategic alignment between business and information technology: A knowledgebased view of behaviors, outcome, and consequences. Journal of Management Information Systems, 23(3), pp. 129-162.

King, W. R. 2009. Planning in information systems: an introduction. In: W. R. King, ed. Planning for Information Systems Advances in Management Information Systems, Volume 14. Armonk: NY, USA: M.E. Sharpe, Inc. pp. 3-16.

Kitsios, F., and Kamariotou, M. 2019a. Digital business strategy and information systems planning: determinants of success. In: European Conference on Innovation and Entrepreneurship, Kalamata, Greece Academic Conferences International Limited. pp. 514-521.

Kitsios, F., and Kamariotou, M. 2019b. Strategizing information systems: an empirical analysis of IT alignment and success in SMEs. Computers, 8(4), pp. 74-88.

Kovacic, A. 2004. Business renovation: business rules (still) the missing link. Business Process Management Journal, 10(2), pp. 158-170.

Lederer, A. L., and Sethi, V. 1988. The implementation of strategic information systems planning methodologies. MIS Quarterly, 12(3), pp. 445-461.

Lee, G. G., and Bai, R. J. 2003. Organizational mechanisms for successful IS/IT strategic planning in the digital era. Management Decision, 41(1), pp. 32-42.

Lee, J. C., and Chen, C. Y. 2019. Investigating the environmental antecedents of organizations' intention to adopt agile software development. Journal of Enterprise Information Management. 32(5), pp. 869-886.

Lee, T., Ghapanchi, A. H., Talaei-Khoei, A., and Ray, P. 2015. Strategic information system planning in healthcare organizations. Journal of Organizational and End User Computing, 27(2), pp. 1-31.

Liang, H., Wang, N., Xue, Y., and Ge, S. 2017. Unraveling the alignment paradox: how does business-IT alignment shape organizational agility? Information Systems Research, 28(4), pp. 863-879.

Lientz, B. P. 2010. Breakthrough: Strategic IT and Process Planning. Hackensack, NJ: World Scientific Publishing Co. Pte. Ltd.

Lin, C., and Hsu, M. L. 2010. Holistic decision system for human resource capability identification. Industrial Management and Data Systems, 110(2), pp. 230-248.

Luftman, J., Zadeh, H. S., Derksen, B., Santana, M., Rigoni, E. H., and Huang, Z. D. 2013. Key information technology and management issues 2012-2013: An international study. Journal of Information Technology, 28(4), pp. 354-366.

Lutchman, R. 2012. Creating and Managing Sustainable Organizations. Lancaster, Pennsylvania: DEStech Publications.

Maharaj, S., and Brown, I. 2015. The impact of shared domain knowledge on strategic information systems planning and alignment. South African Journal of Information Management, 17(1), pp. 1-12.

McNurlin, B. C., Sprague Jr, R. H., and Bui, T. 2009. Information Systems Management in Practice. $8^{\text {th }}$ ed. Upper Saddle River, New Jersey: Pearson Prentice Hall.

Merali, Y., Papadopoulos, T., and Nadkarni, T. 2012. Information systems strategy: past, present, future? The Journal of Strategic Information Systems, 21(2), pp. 125-153.

Mirchandani, D. A., and Lederer, A. L. 2012. Less is more: information systems planning in an uncertain environment. Information Systems Management, 29(1), pp. 13-25.

National Information Society Agency (NIA). 2017. 2017 Informatization White paper. NIA: Republic of Korea.

National Information Society Agency (NIA). 2019. Informatization White paper. NIA: Republic of Korea.

National IT Industry Promotion Agency (NIPA). 2012. The e-business and IT use survey of Korean Enterprises, NIPA: Republic of Korea.

Newkirk, H. E., and Lederer, A. L. 2006. Incremental and comprehensive strategic information systems planning in an uncertain environment. IEEE Transactions on Engineering Management, 53(3), pp. 380-394.

Newkirk, H. E., and Lederer, A. L. 2007. The effectiveness of strategic information systems planning for technical resources, personnel resources and data security in environments of heterogeneity and hostility. Journal of Computer Information Systems, 47(3), pp. 34-44. 
Newkirk, H. E., Lederer, A. L., and Johnson, A. M. 2008. Rapid business and IT change:drivers for strategic information systems planning? European Journal of Information Systems, 17(3), pp. 198-218.

Olfman, L., and Pitsatorn, P. 2000. End-user training research: status and models for the future. In: R.W. Zmud, ed. Framing the domains of IT management: Projecting the future through the past Cincinnati, OH: Pinnaflex. pp. 129-146.

Öri, D. 2018. Towards a prospective use of EAM in supporting SISP: a case study. In: 2018 12th International Conference on Software, Knowledge, Information Management \& Applications (SKIMA) Phnom Penh, Cambodia: IEEE. pp. 1-6.

Otim, S., Grover, V., and Segars, A. H. 2009. The role of organizational learning in strategic information systems planning in uncertain environment. In: King, W. R., ed. Planning for information systems Advances in Management Information Systems, Volume 14. M.E. Armonk NY, USA: M. E. Sharpe, Inc. pp. 233-256.

Oyemomi, O., Liu, S., Neaga, I., Chen, H., \& Nakpodia, F. 2019. How cultural impact on knowledge sharing contributes to organizational performance: using the fsQCA approach. Journal of Business Research, 94, pp. 313-319.

Pai, J. C. 2006. An empirical study of the relationship between knowledge sharing and IS/IT strategic planning (ISSP). Management Decision, 44(1), pp. 105-122.

Palanisamy, R. 2005. Strategic information systems planning model for building flexibility and success. Industrial Management and Data Systems, 105(1), pp. 63-81.

Papke-Shields, K. E., Malhotra, M. K., and Grover, V. 2002. Strategic manufacturing planning systems and their linkage to planning systems success. Decision Sciences, 33(1), pp. 1-30.

Park, S., and Kim, E. J. (2018). Fostering organizational learning through leadership and knowledge sharing. Journal of Knowledge Management, 22(6), pp. 1408-1423.

Parolia, N., Goodman, S., Li, Y., and Jiang, J. J. 2007. Mediators between coordination and IS project performance. Information and Management, 44(7), pp. 635-645.

Peppard, J. and Ward, J. 2004. Beyond strategic information systems: Towards an IS capability. Journal of Strategic Information Systems, 13(2), pp. 167-194.

Peppard, J., and Ward, J. 2016. The strategic planning for information systems: building a digital strategy. Chichester: John Wiley and Sons Ltd.

Peppard, J., Galliers, R. D., and Thorogood, A. 2014. Information systems strategy as practice: Micro strategy and strategizing for IS. The Journal of Strategic Information Systems, 23(1), pp. 1-10.

Philip, G. 2007. IS strategic planning for operational efficiency. Information Systems Management, 24(3), pp. 247-264.

Philip, G. 2009. Some dos and don'ts of strategic information systems planning. In: W. R: King, ed. Planning for Information Systems Advances in Management Information Systems, Volume 14. Armonk NY, USA: M.E. Sharpe, Inc. pp. 189-208.

Piccoli, G. 2008. Information systems for managers: Text and cases. Hoboken, New Jersey: John Wiley and Sons, Inc.

Preston, D. S., and Karahanna, E. 2009. Antecedents of IS strategic alignment: A nomological network. Information Systems Research, 20(2), pp. 159-179.

Rainey, D. L. 2010. Enterprise-wide strategic management: achieving sustainable success through leadership, strategies, and value creation. Cambridge, UK: Cambridge University Press.

Ravichandran, T. 2018. Exploring the relationships between IT competence, innovation capacity and organizational agility. The Journal of Strategic Information Systems, 27(1), pp. 22-42.

Reich, B. H., and Benbasat, I. 2000. Factors that influence the social dimension of alignment between business and information technology objectives. MIS Quarterly, 24(1), pp. 81-113.

Roberts, N., and Grover, V. 2012. Leveraging information technology infrastructure to facilitate a firm's customer agility and competitive activity: An empirical investigation. Journal of Management Information Systems, 28(4), pp. 231-270.

Sabherwal, R., Sabherwal, S., Havakhor, T., and Steelman, Z. 2019. How does strategic alignment affect firm performance? The roles of information technology investment and environmental uncertainty. MIS Quarterly, 43(2), pp. 453-474.

Salmela, H., Lederer, A. L., and Reponen, T. 2000. Information systems planning in a turbulent environment. European Journal of Information Systems, 9(1), pp. 3-15.

Samaha, K., and Baki, A. 2009. An exploratory study of the relevance of transnational global information systems to small and medium enterprises: evidence from Egypt. International Journal of Management and Decision Making, 10(1), pp. 432.

Segars, A. H., and Grover, V. 1998. Strategic information systems planning: An investigation of the construct and its measurement. MIS Quarterly, 22(2), pp. 139-163.

Segars, A. H., and Grover, V. 1999. Profiles of strategic information systems planning. Information Systems Research, 10(3), pp. 199-232.

Shao, Z. 2019. Interaction effect of strategic leadership behaviors and organizational culture on IS-Business strategic alignment and Enterprise Systems assimilation. International Journal of Information Management, 44, pp. 96-108.

Sharma, R., and Yetton, P. 2007. The contingent effects of training, technical complexity, and task interdependence on successful information systems implementation. MIS Quarterly, 31(2), pp. 219-239.

Silvius, A. J., and Stoop, J. 2013. The relationship between strategic information systems planning situational factors, process configuration and success. Journal of International Technology and Information Management, 22(1), pp. 1-15.

Spil, T. A., van den Broek, T., and Salmela, H. T. 2010. It takes two to tango: the fit between network context and interorganizational strategic information systems planning. International Journal of Strategic Information Technology and Applications, 1(1), pp. 23-41. 
Stemberger, M. I., Manfreda, A., and Kovacic, A. 2011. Achieving top management support with business knowledge and role of IT/IS personnel. International Journal of Information Management, 31(5), pp. 428-436.

Tai, J. C., Wang, E. T., and Yeh, H. Y. 2019. A study of IS assets, IS ambidexterity, and IS alignment: the dynamic managerial capability perspective. Information \& Management, 56(1), pp. 55-69.

Tallon, P. P. 2007. A process-oriented perspective on the alignment of information technology and business strategy. Journal of Management Information Systems, 24(3), pp. 227-268.

Tallon, P. P. 2009. How information technology infrastructure flexibility shapes strategic alignment: A case study investigation with implications for strategic IS planning. In: W.R. King, ed. Planning for Information Systems Advances in Management Information Systems, Volume 14. Armonk NY, USA: M.E. Sharpe, Inc. pp. 413-443.

Teo, T. S. H. 2009. Aligning business and information systems. In: W.R. King, ed. Planning for Information Systems Advances in Management Information Systems, Volume 14. Armonk, NY, USA: M.E. Sharpe, Inc. pp. 68-95.

Teo, T. S. H., and Ang, J. S. K. 2001. An examination of major IS problems. International Journal of Information Management, 21(6), pp. 457-470.

Teubner, R. A. 2013. Information systems strategy. Business \& Information Systems Engineering, 5(4), pp. 243-257.

Urbach, N., Ahlemann, F., Böhmann, T., Drews, P., Brenner, W., Schaudel, F., and Schütte, R. 2019. The impact of digitalization on the IT department, Business \& Information Systems Engineering, 61(1), pp. 123-131.

Wallace, P. 2013. Information systems in organizations: People, technology, and processes. Upper Saddle River, New Jersey: Pearson Education, Inc.

Wang, E. T. G., and Tai, J. C. F. 2003. Factor affecting information systems planning effectiveness: Organizational contexts and planning systems dimensions. Information and Management, 40(4), pp. 287-303.

Wilkin, C. L., and Chenhall, R. H. 2010. A review of IT governance: a taxonomy to inform accounting information systems. Journal of Information Systems, 24(2), pp. 107-146.

Yeh, C. H., Lee, G. G., and Pai, J. C. 2011. Influence of CIO'S knowledge-sharing behavior on the quality of the IS/IT strategic planning (ISSP) process in Taiwan. African Journal of Business Management, 5(6), pp. 2465-2474.

Young, R., and Jordan, E. 2008. Top management support: Mantra or necessity? International Journal of Project Management, 26(7), pp. 713-725.

Zwass, V. 2009. Series editor's introduction. In: W. R King, ed. Planning for information systems (ix-xii), Advances in management information systems, Volume 14. Armonk, NY, USA: M.E. Sharpe, Inc. 


\section{Appendix: The outcome of the Exploratory Factor Analysis model}

The outcome of EFA (Facilitators)

KMO and Bartlett's Test

\begin{tabular}{|c|c|c|}
\hline \multicolumn{2}{|c|}{ Kaiser-Meyer-Olkin Measure of Sampling Adequacy. } & $\begin{array}{r}.926 \\
4547.286\end{array}$ \\
\hline \multirow[t]{2}{*}{ Bartlett's Test of Sphericity } & $\mathrm{df}$ & 325 \\
\hline & Sig. & .000 \\
\hline
\end{tabular}

Total Variance Explained

\begin{tabular}{|c|c|c|c|c|c|c|c|c|c|}
\hline \multirow[t]{2}{*}{ Component } & \multicolumn{3}{|c|}{ Initial Eigenvalues } & \multicolumn{3}{|c|}{$\begin{array}{c}\text { Extraction Sums of Squared } \\
\text { Loadings }\end{array}$} & \multicolumn{3}{|c|}{$\begin{array}{c}\text { Rotation Sums of Squared } \\
\text { Loadings }\end{array}$} \\
\hline & Total & $\begin{array}{c}\% \text { of } \\
\text { Variance }\end{array}$ & $\begin{array}{l}\text { Cumulati } \\
\text { ve } \%\end{array}$ & Total & $\begin{array}{c}\% \text { of } \\
\text { Variance }\end{array}$ & $\begin{array}{l}\text { Cumulati } \\
\text { ve } \%\end{array}$ & Total & $\begin{array}{c}\% \text { of } \\
\text { Variance }\end{array}$ & $\begin{array}{c}\text { Cumulativ } \\
\text { e \% }\end{array}$ \\
\hline 1 & 11.730 & 45.116 & 45.116 & 11.730 & 45.116 & 45.116 & 4.523 & 17.395 & 17.395 \\
\hline 2 & 2.281 & 8.774 & 53.889 & 2.281 & 8.774 & 53.889 & 4.282 & 16.468 & 33.863 \\
\hline 3 & 1.787 & 6.872 & 60.761 & 1.787 & 6.872 & 60.761 & 3.249 & 12.497 & 46.360 \\
\hline 4 & 1.410 & 5.424 & 66.185 & 1.410 & 5.424 & 66.185 & 3.230 & 12.424 & 58.785 \\
\hline 5 & 1.022 & 3.929 & 70.114 & 1.022 & 3.929 & 70.114 & 2.946 & 11.330 & 70.114 \\
\hline 6 & .728 & 2.801 & 72.916 & & & & & & \\
\hline 7 & .675 & 2.596 & 75.512 & & & & & & \\
\hline 8 & .644 & 2.478 & 77.990 & & & & & & \\
\hline 9 & .591 & 2.274 & 80.264 & & & & & & \\
\hline 10 & .554 & 2.130 & 82.394 & & & & & & \\
\hline 11 & .453 & 1.742 & 84.136 & & & & & & \\
\hline 12 & .426 & 1.637 & 85.773 & & & & & & \\
\hline 13 & .387 & 1.490 & 87.264 & & & & & & \\
\hline 14 & .377 & 1.449 & 88.713 & & & & & & \\
\hline 15 & .356 & 1.370 & 90.083 & & & & & & \\
\hline 16 & .318 & 1.225 & 91.308 & & & & & & \\
\hline 17 & .301 & 1.159 & 92.467 & & & & & & \\
\hline 18 & .298 & 1.146 & 93.613 & & & & & & \\
\hline 19 & .277 & 1.065 & 94.677 & & & & & & \\
\hline 20 & .258 & .993 & 95.670 & & & & & & \\
\hline 21 & .241 & .926 & 96.597 & & & & & & \\
\hline 22 & .218 & .839 & 97.435 & & & & & & \\
\hline 23 & .184 & .706 & 98.141 & & & & & & \\
\hline 24 & .181 & .696 & 98.838 & & & & & & \\
\hline 25 & .176 & .675 & 99.513 & & & & & & \\
\hline 26 & .127 & .487 & 100.000 & & & & & & \\
\hline
\end{tabular}

Extraction Method: Principal Component Analysis. 
Rotated Component Matrix ${ }^{\mathrm{a}}$

\begin{tabular}{|l|c|c|c|c|c|}
\hline & \multicolumn{5}{|c|}{ Component } \\
\cline { 2 - 6 } & 1 & 2 & 3 & 4 & 5 \\
\hline TMPS Item 1 & & .784 & & & \\
TMPS Item 2 & & .800 & & & \\
TMPS Item 3 & & .781 & & & \\
TMPS Item 4 & & .744 & & & \\
TMPS Item 5 & & .747 & & & \\
TMPS Item 6 & & .723 & & & \\
ACKS Item 1 & .694 & & & & \\
ACKS Item 2 & .699 & & & & \\
ACKS Item 3 & .721 & & & & \\
ACKS Item 4 & .729 & & & & \\
ACKS Item 5 & .739 & & & & \\
ACKS Item 6 & .730 & & & .733 \\
ACKS Item 7 & .733 & & & & \\
CIEE Item 1 & & & .751 & & \\
CIEE Item 2 & & & .731 & & \\
CIEE Item 3 & & & .780 & & \\
CIEE Item 4 & & & .811 & & \\
POL Item 1 & & & & .629 & \\
POL Item 2 & & & & .676 & \\
POL Item 3 & & & & & \\
POL Item 4 & & & & & \\
POL Item 5 & & & & & \\
ARA Item 1 & & & & & \\
ARA Item 2 & & & & & \\
ARA Item 3 & & & & & \\
ARA Item 4 & & & & & \\
\hline
\end{tabular}

Extraction Method: Principal Component Analysis.

Rotation Method: Varimax with Kaiser Normalization.a

a. Rotation converged in 6 iterations.

The outcome of EFA (SISP success)

KMO and Bartlett's Test

\begin{tabular}{|c|c|c|}
\hline \multicolumn{2}{|c|}{ Kaiser-Meyer-Olkin Measure of Sampling Adequacy. } & $\begin{array}{r}.914 \\
1255.260\end{array}$ \\
\hline \multirow[t]{2}{*}{ Bartlett's Test of Sphericity } & $\mathrm{df}$ & 55 \\
\hline & Sig. & .000 \\
\hline
\end{tabular}

Total Variance Explained

\begin{tabular}{|c|r|r|r|r|r|r|}
\hline \multirow{2}{*}{ Component } & \multicolumn{3}{|c|}{ Initial Eigenvalues } & \multicolumn{3}{|c|}{ Extraction Sums of Squared Loadings } \\
\cline { 2 - 7 } & \multicolumn{1}{|c|}{ Total } & \% of Variance & Cumulative \% & Total & \% of Variance & Cumulative \% \\
\hline 1 & 5.580 & 50.730 & 50.730 & 5.580 & 50.730 & 50.730 \\
2 & .990 & 9.003 & 59.732 & & & \\
3 & .877 & 7.974 & 67.707 & & & \\
4 & .614 & 5.582 & 73.289 & & & \\
5 & .549 & 4.993 & 78.283 & & & \\
6 & .476 & 4.331 & 82.614 & & & \\
7 & .451 & 4.101 & 86.715 & & & \\
8 & .439 & 3.994 & 90.709 & & & \\
9 & .402 & 3.651 & 94.360 & & & \\
10 & .345 & 3.132 & 97.492 & & & \\
11 & .276 & 2.508 & 100.000 & & & \\
\hline
\end{tabular}

Extraction Method: Principal Component Analysis. 


\begin{tabular}{|l|r|}
\hline \multicolumn{2}{|c}{ Component Matrix } \\
\hline \multicolumn{1}{|c|}{ Component } \\
\cline { 2 - 2 } & \multicolumn{1}{|c|}{1} \\
\hline BITSA Item 1 & .712 \\
BITSA Item 2 & .692 \\
BITSA Item 3 & .696 \\
BITSA Item 4 & .670 \\
BITSA Item 5 & .701 \\
\hline
\end{tabular}

Extraction Method: Principal

Component Analysis.

a. 1 components extracted.

The outcome of EFA (The outcome of SISP success)

KMO and Bartlett's Test

\begin{tabular}{|c|c|c|}
\hline \multicolumn{2}{|c|}{ Kaiser-Meyer-Olkin Measure of Sampling Adequacy. } & $\begin{array}{r}.921 \\
1513.982\end{array}$ \\
\hline \multirow[t]{2}{*}{ Bartlett's Test of Sphericity } & $\mathrm{df}$ & 78 \\
\hline & Sig. & .000 \\
\hline
\end{tabular}

Total Variance Explained

\begin{tabular}{|c|r|r|r|r|r|r|r|r|r|}
\hline \multirow{2}{*}{ Component } & \multicolumn{3}{|c|}{ Initial Eigenvalues } & \multicolumn{3}{c|}{ Extraction Sums of Squared } \\
Loadings
\end{tabular}

Extraction Method: Principal Component Analysis. 
Rotated Component Matrix ${ }^{\mathrm{a}}$

\begin{tabular}{|l|l|l|}
\hline \multirow{2}{*}{} & \multicolumn{2}{|c|}{ Component } \\
\cline { 2 - 3 } & 1 & 2 \\
\hline Orcap Item 1 & .650 & \\
Orcap Item 2 & .770 & \\
Orcap Item 3 & .746 & \\
Orcap Item 4 & .732 & \\
Orcap Item 5 & .652 & \\
Orcap Item 6 & .703 & \\
Orcap Item 7 & .644 & \\
ITIF Item 1 & & .718 \\
ITIF Item 2 & & .670 \\
ITIF Item 3 & & .701 \\
ITIF Item 4 & & .780 \\
ITIF Item 5 & & .731 \\
ITIF Item 6 & & .689 \\
\hline
\end{tabular}

Extraction Method: Principal

Component Analysis.

Rotation Method: Varimax with

Kaiser Normalization.a

a. Rotation converged in 3

iterations. 